\section{Keywords: Tank Farm \\ Characterization \\ Salt Dissolution \\ Draining \\ Gibbsite}

Retention: Permanent

\title{
Tank 29H Saltcake Core and Supernate Sample Analysis
}

\author{
C. J. Martino \\ D. J. McCabe \\ R. L. Nichols
}

Publication date: April 6, 2004

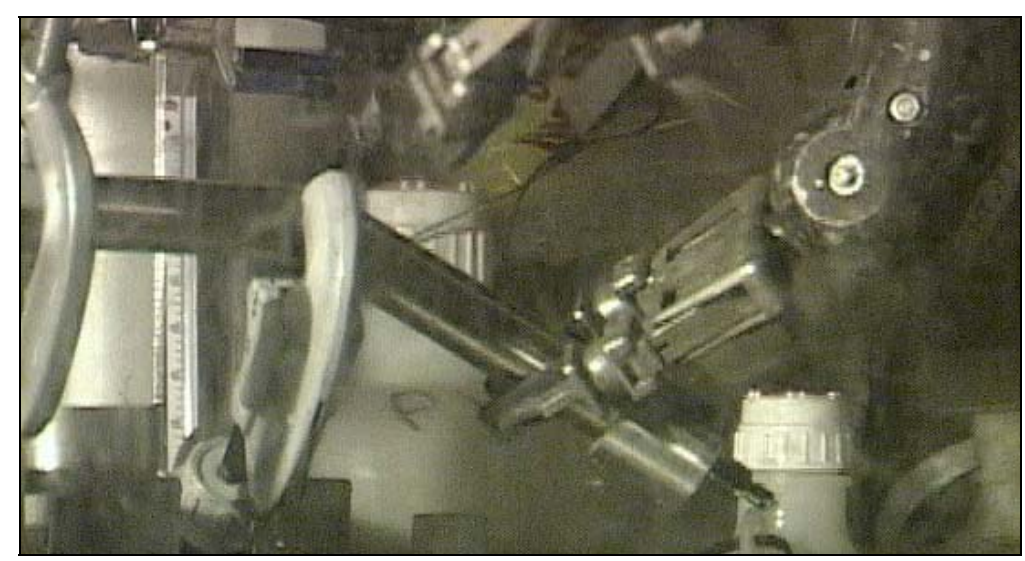

Westinghouse

Savannah River Company

Aiken, SC 29808 
This document was prepared in conjunction with work accomplished under Contract No. DE-AC09-96SR18500 with the U. S. Department of Energy.

\section{DISCLAIMER}

This report was prepared as an account of work sponsored by an agency of the United States Government. Neither the United States Government nor any agency thereof, nor any of their employees, makes any warranty, express or implied, or assumes any legal liability or responsibility for the accuracy, completeness, or usefulness of any information, apparatus, product or process disclosed, or represents that its use would not infringe privately owned rights. Reference herein to any specific commercial product, process or service by trade name, trademark, manufacturer, or otherwise does not necessarily constitute or imply its endorsement, recommendation, or favoring by the United States Government or any agency thereof. The views and opinions of authors expressed herein do not necessarily state or reflect those of the United States Government or any agency thereof.

This report has been reproduced directly from the best available copy.

Available for sale to the public, in paper, from: U.S. Department of Commerce, National Technical Information Service, 5285 Port Royal Road, Springfield, VA 22161, phone: (800) 553-6847, fax: (703) 605-6900

email: orders@ntis.fedworld.gov

online ordering: http://www.ntis.gov/help/index.asp

Available electronically at http://www.osti.gov/bridge

Available for a processing fee to U.S. Department of Energy and its contractors, in paper, from: U.S. Department of Energy, Office of Scientific and Technical Information, P.O. Box 62, Oak Ridge, TN 37831-0062,

phone: (865)576-8401,

fax: (865)576-5728

email: $\underline{\text { reports@ adonis.osti.gov }}$ 


\section{Summary}

This report provides the final results of analyses of the saltcake core sample and a separate supernate sample from Tank $29 \mathrm{H}$. The portion of undrained saltcake that was analyzed contained a relatively large amount of aluminum (13 wt\%), had a bulk density of $2.13 \mathrm{~g} / \mathrm{cm}^{3}$, a water content of $21.4 \mathrm{wt} \%$, and a ${ }^{137} \mathrm{Cs}$ activity of $5.2 \mathrm{Ci}$ per gallon of saltcake. The drained interstitial liquid had a ${ }^{137} \mathrm{Cs}$ activity of $9.5 \mathrm{Ci}$ per gallon.

The supernate sample was markedly different from the drained interstitial liquid, with a ${ }^{137} \mathrm{Cs}$ content of $2.6 \mathrm{Ci} / \mathrm{gal}$. The Tank $29 \mathrm{H}$ supernate had a reduction in ${ }^{238} \mathrm{Pu}$ from $1.32 \mathrm{E}+5 \mathrm{pCi} / \mathrm{mL}$ to $3.65 \mathrm{E}+4 \mathrm{pCi} / \mathrm{mL}$ upon filtering through a 0.45 -micron filter. Approximately $25 \%$ of the $U$ is in suspension in the supernate and can be removed by filtration.

As expected, the radionuclides Cs-137 and Tc-99 are entirely soluble and the actinides are largely $(>90 \%)$ insoluble, in the interstitial liquid, within experimental error.

It is not known how representative this saltcake sample is for the entire tank. There is considerably more liquid present in this sample than in most other tank samples examined thus far. The history of the tank indicates that some of the saltcake in the top layer likely dissolved by the addition of low ionic strength solutions over the past few years. Also, the sample was collected at the bottom of a 7-foot well that was mined into the saltcake with water. These water additions could have dissolved the sodium nitrate in the top layer, and left behind a layer containing the remaining salts, including those of aluminum, although it is not possible to confirm this with this sample. Conversely, if this high aluminum composition is similar throughout the tank, more interstitial liquid may be released upon draining, and more will be retained by the remaining saltcake. The draining characteristics of a high aluminum composition waste are also expected to be different from those of sodium nitrate, although the impact is not known. The high concentration of aluminum species led to precipitation of aluminum hydroxide during a draining/dissolution test using deionized water. If this occurs during tank retrieval, it has significant impacts for tank waste retrieval schedules. This phenomenon would likely manifest as slow dissolution and percolation rates, depending on the volume of the high aluminum region, and the method of water addition. Further study is recommended to examine the quantity and conditions for sodium hydroxide additions needed to avoid precipitation of aluminum hydroxide. Even if this sample is not representative of the tank, the presence of layers of high aluminum-containing phases could cause formation of low permeability layers during subsequent dissolutions.

Only about $66 \%$ (by mass) of the original saltcake sample dissolved during the drain/dissolution demonstration using deionized water. The sum of aluminum that was removed in all the dissolution steps was only $27 \%$ of the total calculated present in the bulk sample. The volume of aluminum hydroxide solids remaining after dissolution was $76 \%$ of the original saltcake sample volume. Although the Pu was largely removed from the dissolved salt by filtration, this may not represent the behavior in a tank environment due to the slow kinetics of Pu dissolution in salt solution. The short contact times and low temperatures used in the experiments will not mimic the conditions in a waste tank. Furthermore, if sodium hydroxide is added to facilitate aluminum dissolution, this will impact the Pu solubility. 
This page was intentionally left blank 


\section{Table of Contents}

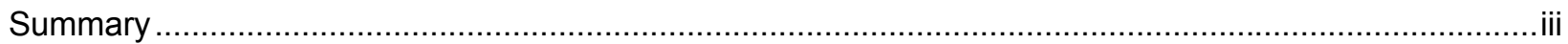

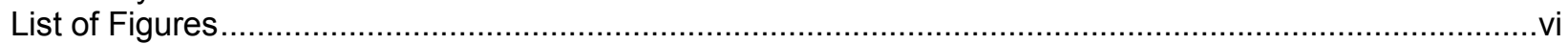

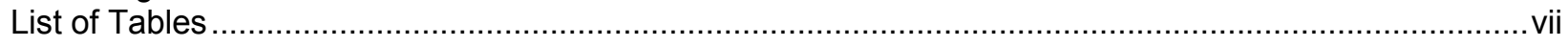

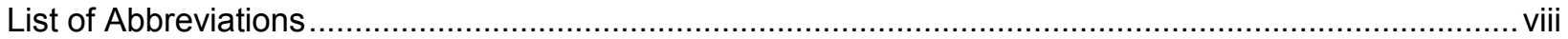

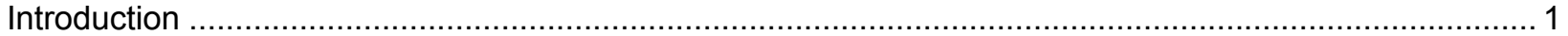

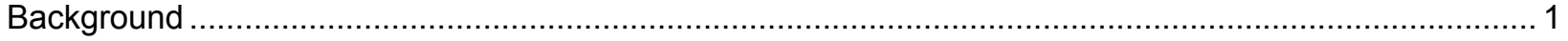

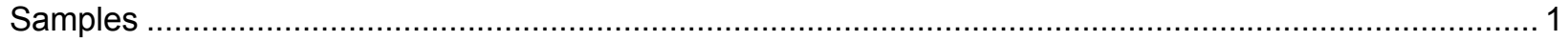

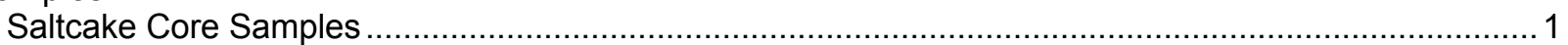

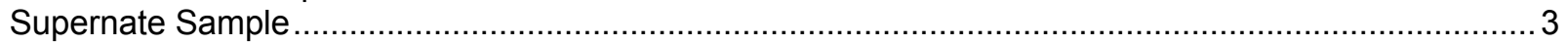

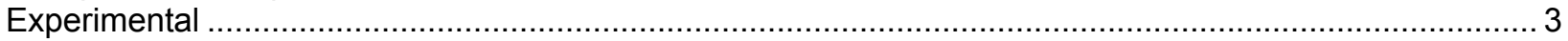

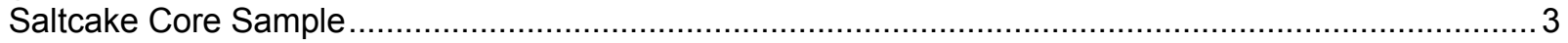

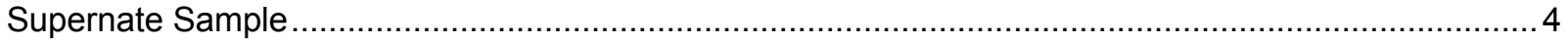

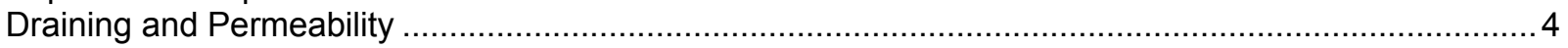

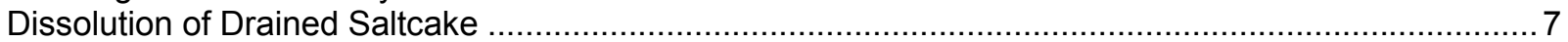

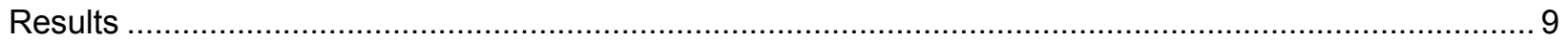

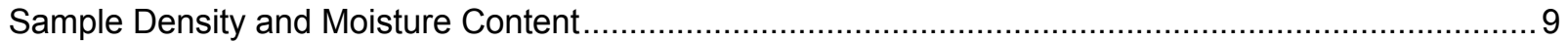

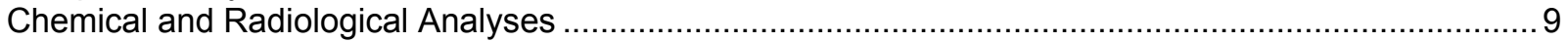

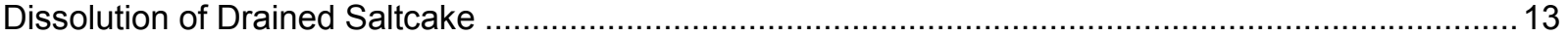

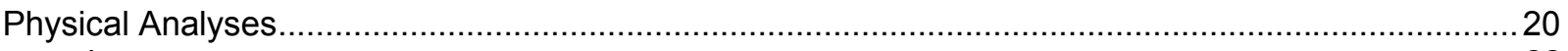

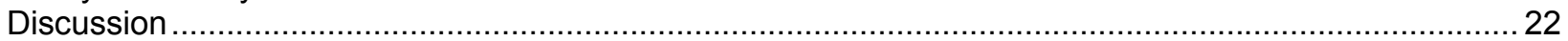

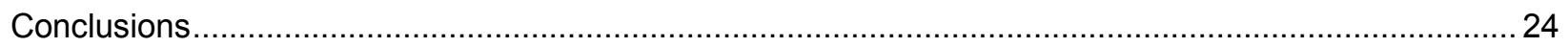

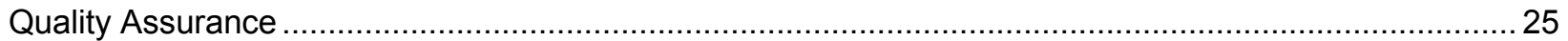

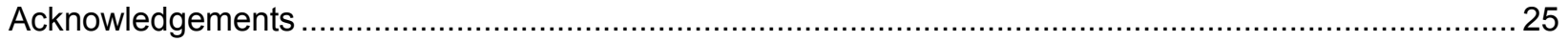

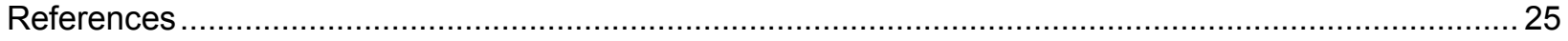

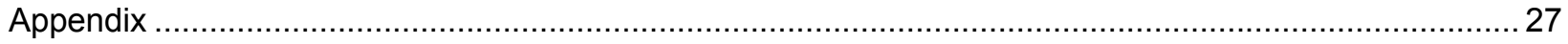


WSRC-TR-2004-00130

Revision 0

\section{List of Figures}

Cover Photo: Cutting the Tank 29H sample in the SRTC shielded cells....................................... i

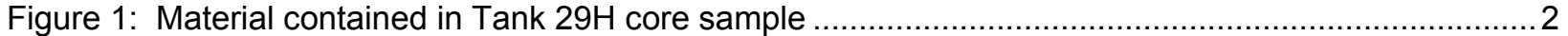

Figure 2: The top, middle (cut), and bottom of the Tank $29 \mathrm{H}$ saltcake core sample ............................. 2

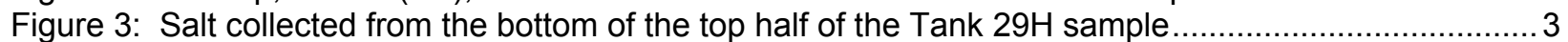

Figure 4: Tank 29H supernate sample HTF-588A, as received (unfiltered) .................................. 3

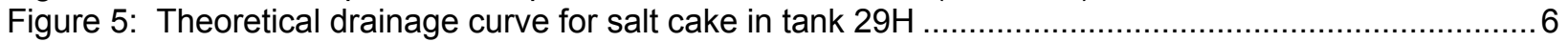

Figure 6: Schematic of apparatus used to extract interstitial liquid from saltcake samples ................... 7

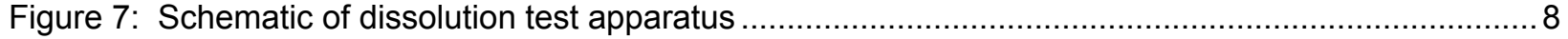

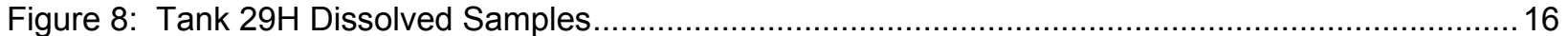

Figure 9: XRD analysis of insoluble solids resulting from dissolution of Tank $29 \mathrm{H}$ saltcake...................17

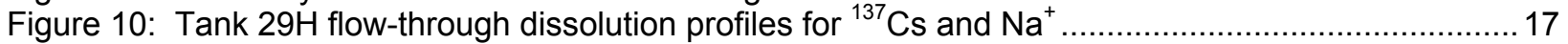

Figure 11: Tank 29H flow-through dissolution profiles for anions and Pu-238 ............................... 18

Figure 12: SEM photograph of solids remaining from dissolution tests....................................... 18

Figure 13: SEM photograph of second area of solids remaining from dissolution tests....................... 19

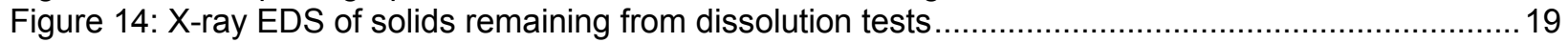

Figure 15: Extraction of interstitial liquid from T29H B6-1-A ................................................. 21

Figure 16: Volume percent of residual and extracted interstitial liquid in T29H-B6-1-A following vacuum

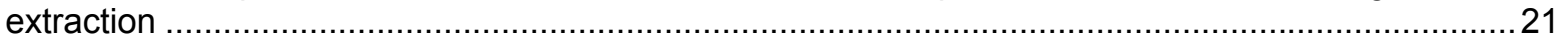

Figure 17: Likely major components of Tank $29 \mathrm{H}$ saltcake solids, normalized ..................................23 


\section{List of Tables}

Table 1: Chemical composition of simulated interstitial liquid used to saturated saltcake samples for falling head permeability test.

Table 2: Density and water content of Tank 29H Samples............................................................

Table 3: Saltcake, Interstitial liquid, and Dip Sample Radiological Analysis Comparison........................10

Table 4: Saltcake, Interstitial liquid, and Dip Sample Principal Component Comparison ....................... 11

Table 5: Saltcake, Interstitial liquid, and Dip Sample Elemental Comparison .................................... 12

Table 6: Likely major components of dry Tank $29 \mathrm{H}$ salt solids, normalized ....................................... 12

Table 7: Tank $29 \mathrm{H}$ drained saltcake dissolution information and analysis of dissolved saltcake for

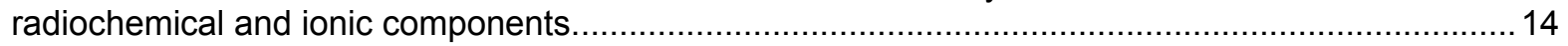

Table 8: Other Elemental Analysis of the Dissolution of Drained Tank 29H Saltcake ........................... 15

Table 9: ICP-MS Analysis of the Dissolution of Drained Tank 29H Saltcake (Bulk Filtered) .................... 16

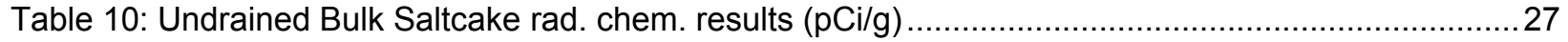

Table 11: Undrained Bulk Saltcake IC Anions, wet chemistry titration, and TIC/TOC results $(\mathrm{g} / 100 \mathrm{~g}) \ldots .27$

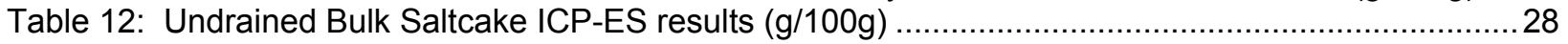

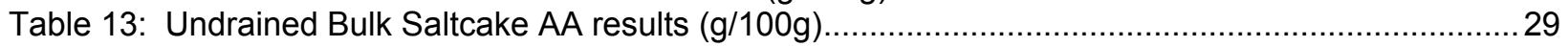

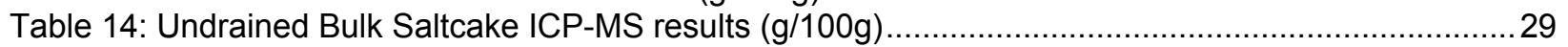

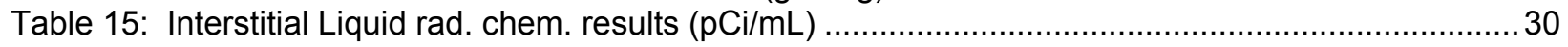

Table 16: Interstitial Liquid IC Anions, wet chemistry titration, and TIC/TOC results (mg/L)..................30

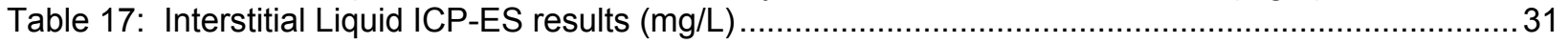

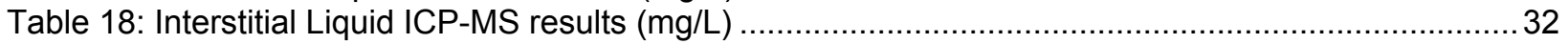

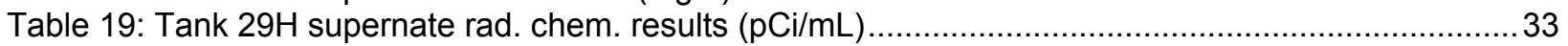

Table 20: Tank 29H supernate IC anions, wet chemistry titration, and TIC/TOC results (mg/L) ............... 33

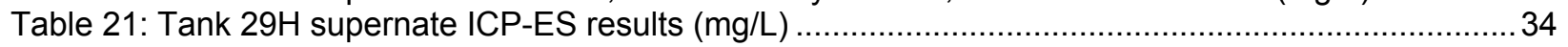

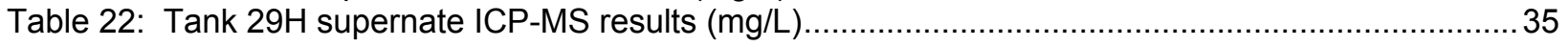

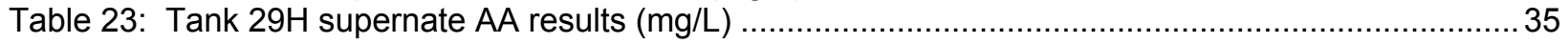


WSRC-TR-2004-00130

Revision 0

$\begin{array}{ll}\text { List of Abbreviations } \\ \text { AA } & \text { Atomic Absorption spectroscopy } \\ \text { ADDS } & \text { Adjusted Drained Dissolved Salt } \\ \text { ADS } & \text { Analytical Development Section } \\ \text { DDS } & \text { Drained Dissolved Salt } \\ \text { DI } & \text { de-ionized } \\ \text { EDS } & \text { X-ray Emission Dispersive Spectroscopy } \\ \text { FL } & \text { Free Liquid supernatant to a saltcake sample upon receipt } \\ \text { ICP-ES } & \text { Inductively-Coupled Plasma - Emission Spectroscopy } \\ \text { ICP-MS } & \text { Inductively-Coupled Plasma - Mass Spectroscopy } \\ \text { IC } & \text { Ion Chromatography } \\ \text { I.D. } & \text { inner diameter } \\ \text { IL } & \text { Interstitial Liquid drained from a saltcake sample } \\ \text { ILD } & \text { Interstitial Liquid Displacement } \\ \text { LCS } & \text { Low-Curie Salt } \\ \text { LWD } & \text { Liquid Waste Disposition } \\ \text { O.D. } & \text { outer diameter } \\ \text { PIL } & \text { Partition into Interstitial Liquid } \\ \text { PLM } & \text { Polarized-Light Microscopy } \\ \text { SEM } & \text { Scanning Electron Microscopy } \\ \text { SIL } & \text { Simulated (non-radioactive) Interstitial Liquid } \\ \text { SL } & \text { Supernatant Liquid from a tank supernate sample } \\ \text { SPF } & \text { Saltstone Processing Facility } \\ \text { SRS } & \text { Savannah River Site } \\ \text { SRTC } & \text { Savannah River Technology Center } \\ \text { TIC } & \text { Total Inorganic Carbon } \\ \text { TOC } & \text { Total Organic Carbon } \\ \text { UDS } & \text { Un-drained Dissolved Salt } \\ \text { WCS } & \text { Waste Characterization System } \\ \text { XRD } & \text { X-Ray Diffraction spectroscopy } \\ & \\ \end{array}$




\section{Introduction}

Recently, the Savannah River Site (SRS) has taken interest in potential processes that could be utilized for accelerated processing of a fraction of High-Level Waste saltcake inventory. In support of this, Liquid Waste Disposition (LWD) has undertaken a program of tank characterization, including salt tank sampling. ${ }^{1,2}$ As part of this initiative, the surface of the Tank $29 \mathrm{H}$ saltcake was sampled using a 12 " long sample tube. The primary objective of the characterization is to gather information that will be useful to the selection and process sequencing of salt tanks. Key process parameters include the ${ }^{137} \mathrm{Cs}$ concentration and liquid retention properties of the Tank $29 \mathrm{H}$ saltcake. Additional chemical analyses are performed to provide information on salt elemental, ionic, and radiological composition to aid in assessment of the suitability of treated material in the disposal facility.

This document serves as the final and comprehensive record of the handling and analyses of the Tank $29 \mathrm{H}$ saltcake core and supernate samples.

\section{Background}

Tank $29 \mathrm{H}$ was the drop tank for the $242-\mathrm{H}(1 \mathrm{H})$ evaporator from 1971 through 1984 . Additional, minor amounts of $1 \mathrm{H}$ evaporator waste were introduced in $1986-1988$. The waste to the tank was characterized as high heat waste. Tank $29 \mathrm{H}$ received steam condensate from the $3 \mathrm{H}$ evaporator separator pot vent line from March, 1999 through January, 2003. Also during that period, nearly all of the free liquid above the saltcake (293 inches) was removed in three transfers, ending in December, 2001. The condensate continued to be added to the tank for more than a year following removal. In addition, about 21,000 gallons of rainwater from the $1 \mathrm{H}$ evaporator CTS pit has been added to the tank in the past three years.

This task documents characterization and dissolution studies performed on the top portion of the saltcake and a supernate surface dip sample that was collected separately.

\section{Samples}

\section{Saltcake Core Samples}

On August 26, 2003, one salt core sample was collected from riser B6 of Tank $29 \mathrm{H}$. The sample was taken from the B6 riser at approximately 206 inches, which is 7 feet lower than the measured tank saltcake level ( 290 inches). The reason it was 7 feet below the recognized tank salt cake level was because the area beneath the B6 riser had been mined out with water in preparation of installing a slurry pump. The temperature of the saltcake in the tank that day was $47^{\circ} \mathrm{C}$, with a supernate temperature of $37^{\circ} \mathrm{C}$. The tank liquid level was 315 inches. Additional samples were planned, but difficulty was encountered in recovering the second sample. This sample was contained in a 0.95 in. I.D., 1.13 in. O.D., $12.7 \mathrm{in}$. long stainless steel tube with capped ends. The sample was delivered to SRTC, placed into the shielded cells, and weighed on August 27.

Sample T29H-B6-1 contained 315.3 grams of saltcake that occupied $147.8 \mathrm{~cm}^{3}$, for a bulk saltcake density of $2.13 \mathrm{~g} / \mathrm{cm}^{3}$. Figure 4 displays the approximate contents of the Tank $29 \mathrm{H}$ sample. The sample contained no supernatant free liquid. In order to complete the required analyses, the sample was divided into two approximately equal halves by cutting the filled tube, and the two halves of the sample tube were renamed (top half is T29H-B6-1-A, and the bottom half is T29H-B6-1-B). Salt for chemical analysis and water content measurement was taken from the bottom of the top half of sample T29H-B6-1-B.

Figure 2 shows the salt that was visible from the ends of the sample tube. From left to right, the images are of the top of the sample, the bottom of the top half of the severed sample, the top of the bottom half of the severed sample, and the bottom of the sample. The salt was white to light yellow/brown in color. The 
middle of the sample glistened and was wetter in appearance than the top and bottom of the sample. Note that the top of the sample tube was filled to the point that no mast threads were visible.

Figure 3 shows the $\sim 50 \mathrm{~g}$ of salt removed from the bottom of the top half of the sample. The salt appeared wet and exhibited thixotropic behavior. For example, when the salt was allowed to sit for $\sim 15$ minutes, the salt set up and resisted flow, and a spatula inserted vertically in the salt could be supported. After mixing the salt and not allowing it to set, a spatula could not be supported.

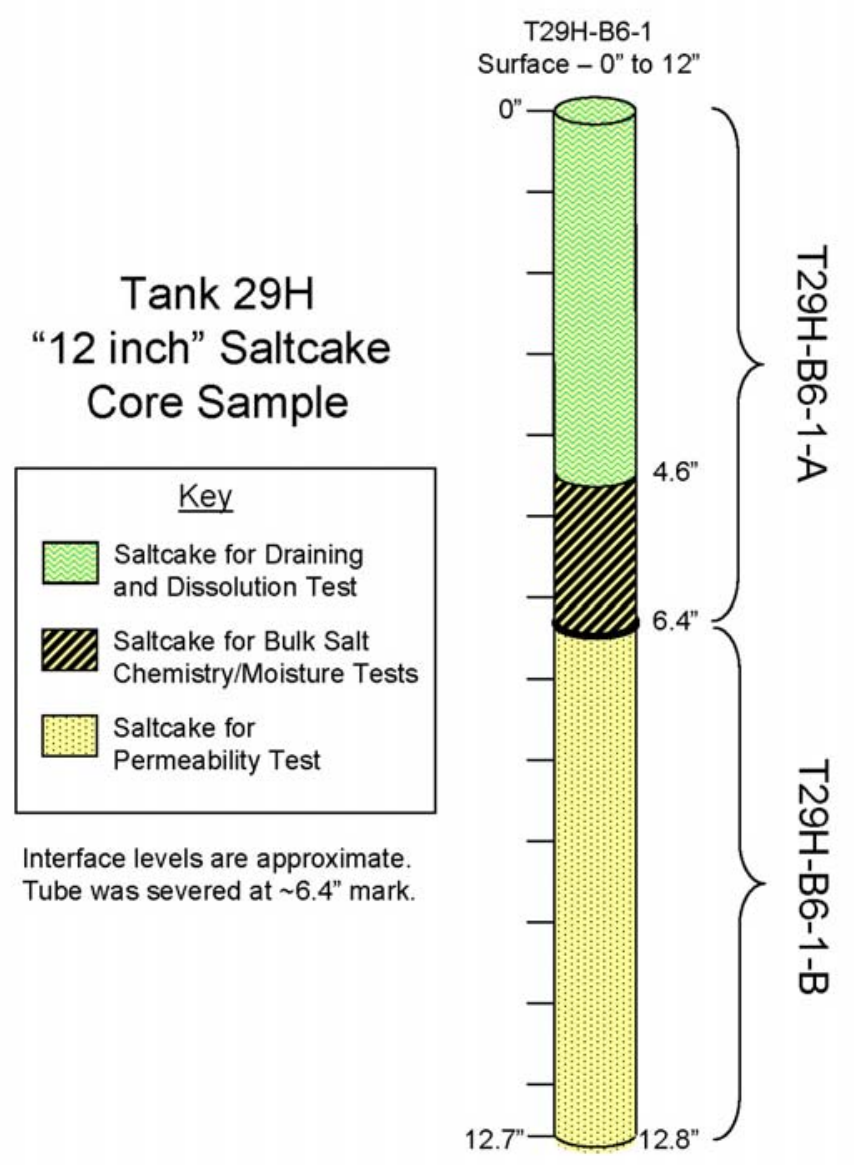

Figure 1: Material contained in Tank 29H core sample
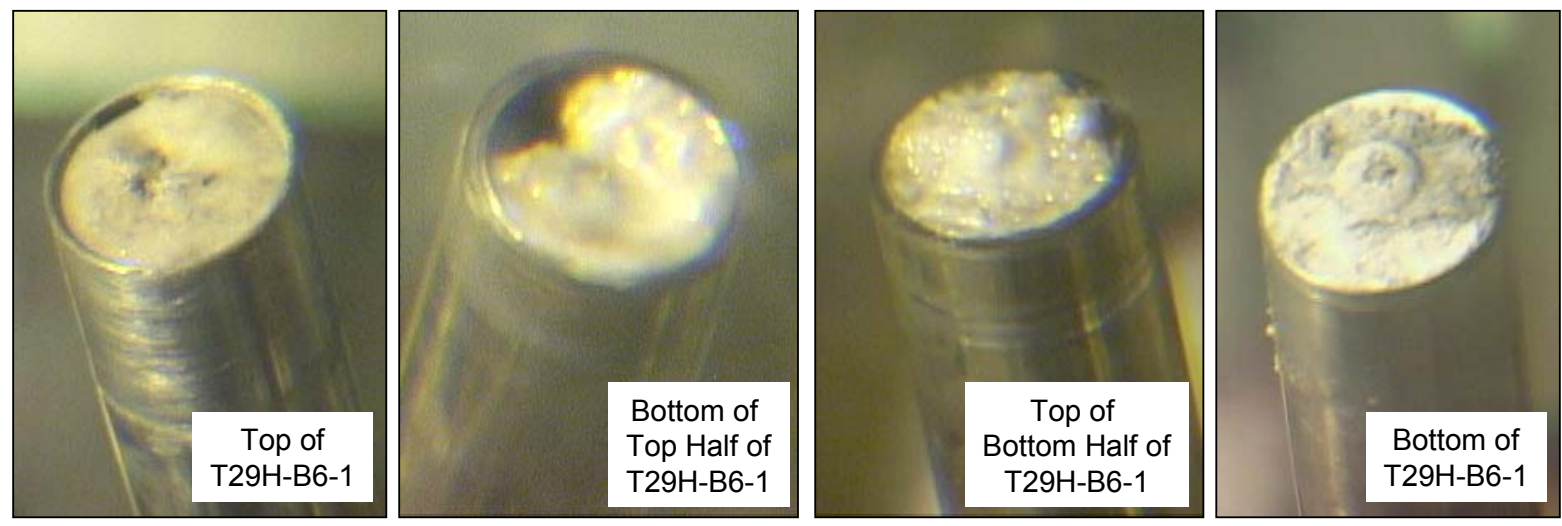

Figure 2: The top, middle (cut), and bottom of the Tank $29 \mathrm{H}$ saltcake core sample 

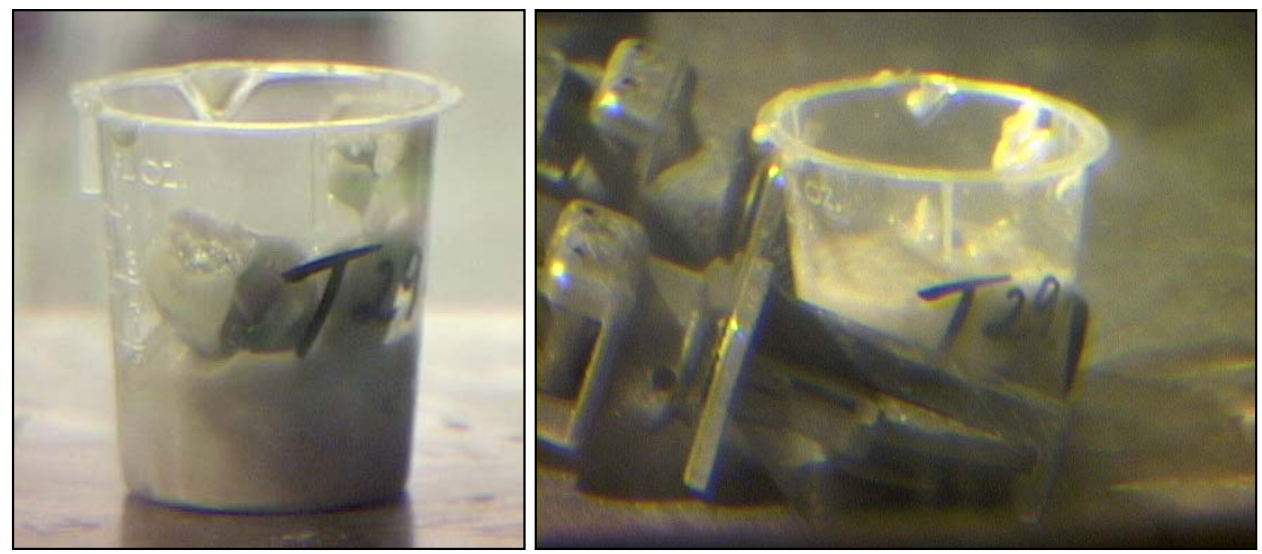

Figure 3: Salt collected from the bottom of the top half of the Tank $29 \mathrm{H}$ sample

\section{Supernate Sample}

On September 11, 2003, SRTC received a supernate sample from Tank $29 \mathrm{H}$. The surface dip sample (HTF-588A) contained $\sim 80 \mathrm{~mL}$ of supernate, pictured in Figure 4. The sample was cloudy with brown insoluble solids.

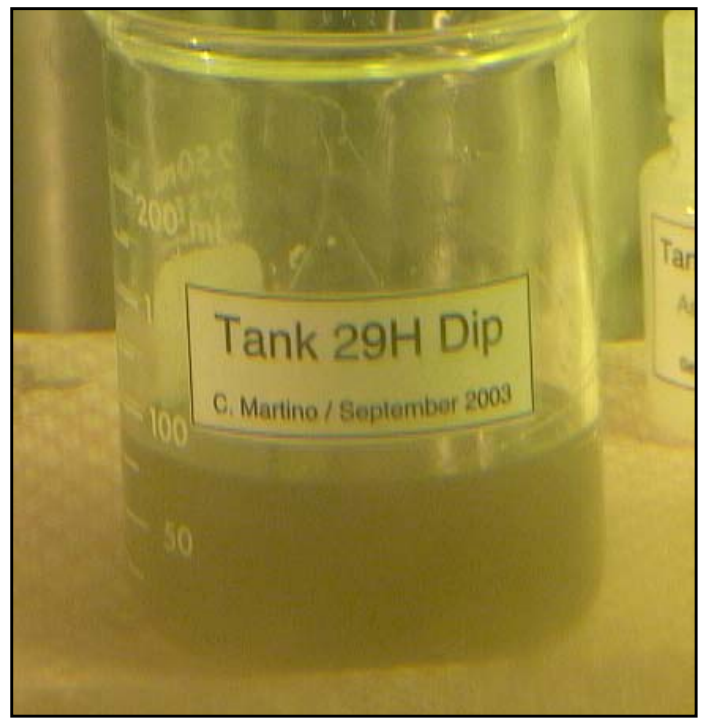

Figure 4: Tank 29H supernate sample HTF-588A, as received (unfiltered)

\section{Experimental}

\section{Saltcake Core Sample}

The core sample (T29H-B6-1) was weighed, uncapped, and visually inspected upon receipt in the shielded cells. The sample was cut into two approximately equal segments and salt was removed from the bottom of the top half of the sample for undrained bulk salt analysis. The remaining portion of the top half of the sample was vacuum drained for two days and the drained interstitial liquid was filtered and analyzed. The drained saltcake was subsequently dissolved with deionized (DI) water using the 
drain/dissolve protocol. Details and analysis of the interstitial liquid and dissolved drained saltcake are provided herein.

Undrained bulk salt characterization was performed on small portions of salt removed from the bottom of the sample tubes. Approximately 50 grams of salt was removed from the bottom of the top half of $\mathrm{T} 29 \mathrm{H}$ B6-1 and analyzed for water content and salt chemistry. Undrained bulk salt subsamples were prepared for analysis either by aqua regia (acid) dissolution or by DI water dissolution. The dissolutions were performed by dissolving approximately 2 grams of the material into $100 \mathrm{~mL}$ of liquid. For the DI water dissolutions, aliquots were taken from the liquid portion after agitation and settling, although no significant solids were visible. The aqua regia dissolutions were submitted to radiological chemistry for ${ }^{137} \mathrm{Cs}$ (gamma scan), Pu isotopics, ${ }^{241} \mathrm{Am}$, and ${ }^{90} \mathrm{Sr}$, inductively coupled plasma - emission spectroscopy (ICPES) for elemental analysis, inductively coupled plasma - mass spectroscopy (ICP-MS) for certain actinide and fission product quantification, and atomic absorption (AA) spectroscopy for the measurement of As, $\mathrm{Se}, \mathrm{Hg}$, and $\mathrm{K}$. The water dilutions/dissolutions were submitted for ion chromatography (IC) for anion characterization, wet chemistry/titration for total base, free hydroxide, and $\mathrm{CO}_{3}{ }^{2-}$ analysis, and total inorganic and organic carbon (TIC/TOC) analysis. An additional portion of the water-dissolved sample was submitted for ${ }^{14} \mathrm{C}$ analysis.

Several analytes require assumptions to be made or calculations and adjustments that require several analytical methods. The ${ }^{99} \mathrm{Tc}$ is reported as a maximum value based on the entire mass 99 data, and thus ignores any contribution of ${ }^{99} \mathrm{Ru}$. The mass 101 values are reported in the appendix in case adjustment of ${ }^{99} \mathrm{Tc}$ for the contribution of natural Ru is desired. Total $\mathrm{Cs}$ is calculated as the sum of ${ }^{133} \mathrm{Cs}$ from ICP-MS and ${ }^{137} \mathrm{Cs}$ from radiochemistry. The ${ }^{135} \mathrm{Cs}$ is reported as a maximum value based on the entire mass 135 data, and thus ignores any contribution of ${ }^{135} \mathrm{Ba}$. This provides a good measurement for the filtered liquid samples because of the limited Ba solubility, but mass 138 values are reported in the appendix in case adjustment of ${ }^{135} \mathrm{Cs}$ for the contribution of natural $\mathrm{Ba}$ is desired. Total Co is reported as mass 59, and thus may be biased high in the presence of organic components that fragment at mass 59. An alternative free hydroxide estimate is provided as a calculated value by taking the total base and subtracting the contribution of aluminate and carbonate ions. Total inorganic carbon is reported as mass of $\mathrm{CO}_{3}{ }^{2}$ and total organic carbon is reported as mass of carbon.

\section{Supernate Sample}

Upon entry into the SRTC shielded cells, the Tank $29 \mathrm{H}$ supernate sample (HTF-588A) was poured into glass beakers to allow for visual observation. Small $(2 \mathrm{~mL})$ portions of the as-received samples were retained for unfiltered analysis. The samples were filtered through 0.45-micron filters and portions of the filtered samples were analyzed. An additional filtration was applied to the $29 \mathrm{H}$ samples using 0.1 -micron filters and portions of the filtrates were analyzed.

Unfiltered and filtered supernate samples were prepared for analysis either by pressurized $\mathrm{HNO}_{3} / \mathrm{HF}$ (acid) dissolution or by DI water dilution. The dissolutions/dilutions were performed by dissolving/diluting approximately 2 grams of the sample with $100 \mathrm{~mL}$ of liquid. Pressurized $\mathrm{HNO}_{3} / \mathrm{HF}$ dissolutions of the filtered and unfiltered samples were submitted to radiological chemistry for ${ }^{137} \mathrm{Cs}$ (gamma scan), Pu isotopics, ${ }^{241} \mathrm{Am}$, and ${ }^{90} \mathrm{Sr}$, ICP-ES for elemental analysis, ICP-MS for certain actinide and fission product quantification, and $\mathrm{AA}$ for the measurement of $\mathrm{As}, \mathrm{Se}, \mathrm{Hg}$, and $\mathrm{K}$. The water dilutions of the filtered samples were submitted to IC for anion characterization, wet chemistry/titration for total base and free hydroxide, TIC/TOC analysis, and radiological chemistry for ${ }^{14} \mathrm{C}$.

\section{Draining and Permeability}

The saltcake bulk density of the as-received material was calculated from a direct measurements of the sample weight and an estimate of the filled volume while the sample was still in the thin walled sample tube. Densities of the interstitial, free, and supernatant liquids were measured as the weight of material required to fill $2 \mathrm{~mL}$ Class $A$ volumetric flasks. The water content of the saltcake $\left(\theta_{\text {water }}\right)$ and liquid 
samples were estimated gravimetrically: small portions $(\sim 1 \mathrm{~g})$ of saltcake or liquid were dried at $115^{\circ} \mathrm{C}$ $\left( \pm 5^{\circ} \mathrm{C}\right)$ to drive off water until a constant weight had been achieved. The solids collected from the filtration of the supernate samples were washed with water and dried for determination of insoluble solids content.

The porosity and saturation of saltcake samples were estimated using the following equations.

$$
\begin{gathered}
\phi=\frac{V_{\text {voids }}}{V_{\text {total }}}=\frac{V_{\text {total }}-V_{\text {solid }}}{V_{\text {total }}} \\
V_{\text {solid }}=\frac{W_{\text {solid }}}{\rho_{\text {solid }}}=\frac{W_{\text {total }}-W_{\text {liquid }}}{\rho_{\text {solid }}} \\
W_{\text {liquid }}=\left(\frac{W_{\text {total }} * \theta_{\text {water }}}{\chi_{\text {wil }}}\right) \\
S=\frac{V_{\text {liquid }}}{V_{\text {voids }}}=\frac{\left(\frac{W_{\text {liquid }}}{\rho_{\text {liquid }}}\right)}{\left(V_{\text {total }} * \phi\right)}
\end{gathered}
$$

$S=$ saturation (fraction)

$\phi=$ porosity (fraction)

$\rho_{\text {soild }}=$ density of solids

$\chi_{\text {wil }}=$ mass fraction of water in interstitial liquid

$\theta_{\text {water }}=$ gravimetric water content

$V_{\text {total }}=$ total volume of sample

$\mathrm{V}_{\text {solid }}=$ volume of solids in sample

$\mathrm{V}_{\text {voids }}=$ volume of sample that does not correspond to solids

$\mathrm{W}_{\text {total }}=$ total weight of sample

$\mathrm{W}_{\text {solid }}=$ weight of solids in sample

$\mathrm{W}_{\text {liquid }}=$ weight of interstitial liquid in sample

Uncertainty in the density of the interstitial liquid, weight percent water, density of solids, and mass fraction of water in interstitial liquid was incorporated into the porosity estimate by performing a Monte Carlo analysis using Crystal Ball 2000 (by Decisioneering, Inc.), an add-in for MS Excel.

A falling head permeability test was conducted on sample T29H-B6-1-B. The permeability test method was similar to that used on saltcake samples from Tank $41 .^{3}$ The sample was not drained prior to initiating saturation with simulated interstitial liquid (SIL). The SIL used to saturate the sample was a 10.8 $\mathrm{M}\left[\mathrm{Na}^{+}\right]$solution with a density of $1.4 \mathrm{~g} / \mathrm{ml}$, as shown in Table 1. 
WSRC-TR-2004-00130

Revision 0

Table 1: Chemical composition of simulated interstitial liquid used to saturated saltcake samples for falling head permeability test.

\begin{tabular}{|l|l|}
\hline \hline Component & Concentration \\
\hline $\mathrm{NaOH}$ & $6.8 \mathrm{M}$ \\
\hline $\mathrm{NaNO} 3$ & $1.5 \mathrm{M}$ \\
\hline $\mathrm{NaNO} 2$ & $2.5 \mathrm{M}$ \\
\hline
\end{tabular}

Interstitial liquid (IL) was extracted from sample T29H-B6-1-A using 10" Hg vacuum for 160 hours. Ten inches of $\mathrm{Hg}$ corresponds to 98 inches of interstitial liquid (assuming a density of $1.4 \mathrm{gm} / \mathrm{cc}$ ) and was selected to drain the sample to average saturation based on the conceptual model for drainage with sandy loam as a porous media analog (Figure 5). ${ }^{4}$ Figure 6 shows the apparatus used to extract the IL. No screen was placed in the bottom shipping cap during vacuum extraction.

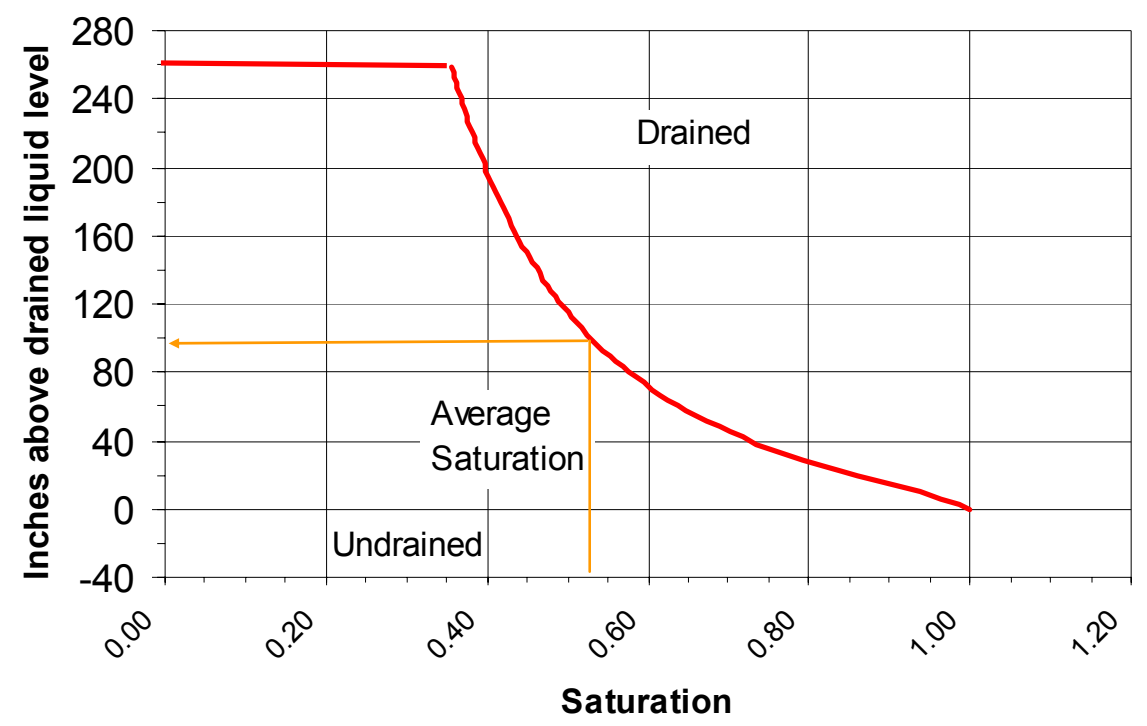

Figure 5: Theoretical drainage curve for salt cake in tank $29 \mathrm{H}$ with the top of salt at 300 inches, final liquid level in caisson of 40 inches, interstitial liquid density of $1.39 \mathrm{gm} / \mathrm{cc}$, and sandy loam drainage curve. 
WSRC-TR-2004-00130

Revision 0

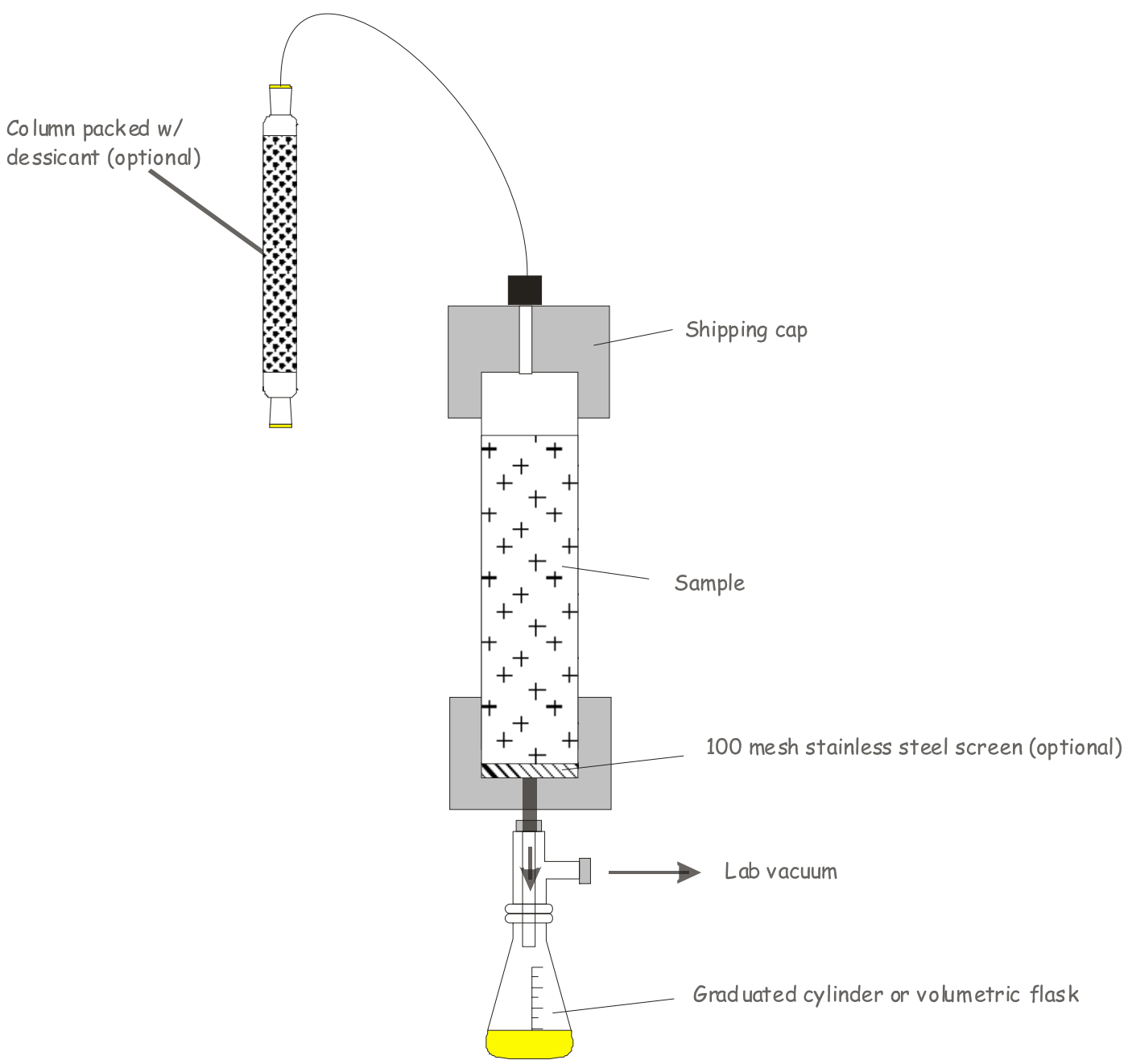

Figure 6: Schematic of apparatus used to extract interstitial liquid from saltcake samples

\section{Dissolution of Drained Saltcake}

Figure 7 contains a generalized illustration of the apparatus used during dissolution testing. The apparatus utilized the remaining drained portion of T29H-B6-1-A (6.4 inch tube with 4.6 inches of salt) in the original $\sim 1$ inch I.D., 1/16 inch wall thickness sampling tube. The dissolution apparatus was essentially the same as the vacuum-extraction apparatus (Figure 6), with the exception of the media bag for water introduction. The orientation of the sample was adjusted so that the larger void in the sample tube would be at the top of the dissolution apparatus. Because salt was removed from the bottom of T26H-B6-1-A for initial testing, the dissolution of T26H-B6-1-A was performed in an orientation that was inverted from the in-tank orientation of the sample. No screen was used at the bottom of the sample during the dissolution protocol. 
WSRC-TR-2004-00130

Revision 0

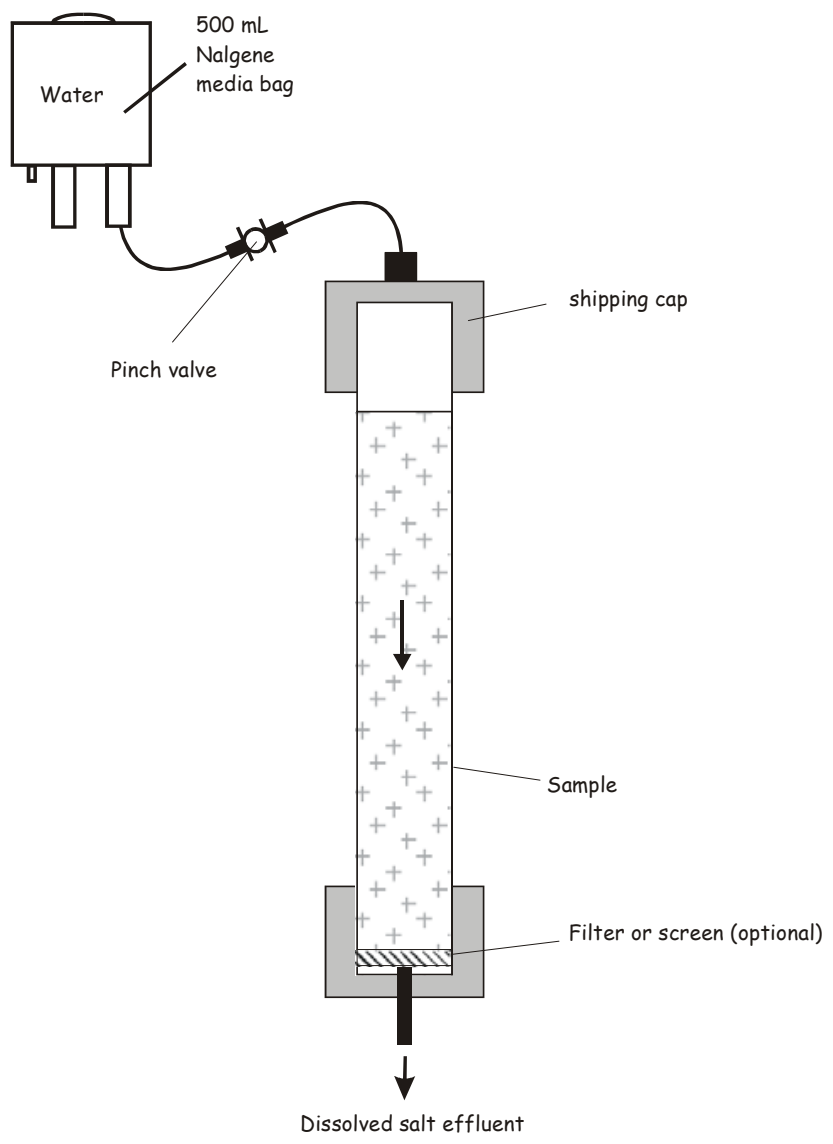

Figure 7: Schematic of dissolution test apparatus

Water was introduced to the top of the sample tube via a media bag and the dissolved salt effluent was collected from the bottom of the sample. The rate of water introduction can be roughly controlled by a pinch valve, but the rate of effluent elution can be limited by the saltcake physical properties. In the case of this Tank $29 \mathrm{H}$ sample, liquid was not evident at the bottom of the sample after several hours of dissolution by gravity draining alone. To assist the flow of dissolution fluid through the sample, vacuum was applied to the bottom of the sample in a manner similar to the process for draining interstitial liquid. During later stages of the dissolution of the Tank $29 \mathrm{H}$ sample, vacuum was no longer needed.

The dissolved salt effluent was periodically sampled in $5 \mathrm{~mL}$ aliquots. The collection of one of these aliquots was timed to obtain an estimate of the effluent flow rate. These aliquots were weighed to obtain the effluent density. During periods of salt dissolution when an aliquot was not collected, the dissolved salt effluent was collected in a larger graduated bottle. For the remainder of this report, the small aliquots are referred to as sub-samples of drained/dissolved saltcake and the larger bottles of effluent are referred to as the bulk drained/dissolved saltcake.

Analysis of the composite bulk drained/dissolved saltcake was performed after filtration of the material through a 0.45 -micron filter. Analysis of sub-samples taken at various stages throughout the flow-through dissolution process was performed without filtration. Subsamples were prepared for chemical and radiochemical analyses at 20 to 50 -times dilutions with $2 \mathrm{M}$ nitric acid and DI water. The nitric acid dilutions were submitted for the same analyses as were the acid dissolutions of the core samples. The analyses included radiological chemistry, ICP-ES, ICP-MS, and AA. The water dilutions of the filtered samples were submitted for IC, wet chemistry titration, and TIC/TOC. The filter was analyzed by microscopy and spectroscopy techniques to identify solid phases and particle size. Two values are reported for ${ }^{99} \mathrm{Tc}$ by ICP-MS: a maximum based on the entire mass 99 data as ${ }^{99} \mathrm{Tc}$, and a minimum number adjusting for the potential ${ }^{99} \mathrm{Ru}$ assuming that the mass 101 result is from natural ${ }^{101} \mathrm{Ru}$. 


\section{Results}

\section{Sample Density and Moisture Content}

The salt removed from the bottom of T29H-B6-1-A had a water content of $21.4 \mathrm{wt} \%$ with a standard deviation of $3.1 \mathrm{wt} \%$, as shown in Table 2 . The half-width of the $95 \%$ confidence interval for the water content was $3.2 \mathrm{wt} \%$. The density of the bulk salt was $2.13 \mathrm{~g} / \mathrm{cm}^{3}$.

Table 2: Density and water content of Tank 29H Samples

\begin{tabular}{|c|c|c|c|c|c|c|c|}
\hline \multirow{2}{*}{ Analyte } & \multirow{2}{*}{ Unit } & \multicolumn{4}{|c|}{ T29H-B6-1 } & \multicolumn{2}{c|}{ HTF-588A } \\
\cline { 3 - 8 } & & \multicolumn{2}{|c|}{ undrained saltcake } & \multicolumn{2}{c|}{ FL (filtered) } & \multicolumn{2}{c|}{ Supernate } \\
\cline { 3 - 8 } & & average & stdev & average & stdev & average & stdev \\
\hline Density & $\mathrm{g} / \mathrm{mL}$ & 2.13 & -- & 1.48 & -- & 1.26 & 0.02 \\
\hline Water & wt \% & 21.4 & 3.1 & 54.7 & -- & 69.8 & -- \\
\hline Liquid & vol \% & 56 & -- & 100 & -- & 100 & -- \\
\hline
\end{tabular}

note: the wt $\%$ water in the filtered liquid was calculated based on summing individual analyses of cations and anions; note the vol\% liquid in the undrained saltcake is calculated based on the wt $\%$ water in saltcake and wt $\%$ water in filtered liquid

Several ( 9) milliliters of interstitial liquid (IL) had been vacuum drained from the remaining portion of $\mathrm{T} 29 \mathrm{H}-\mathrm{B} 6-1-\mathrm{A}$. The density of the interstitial liquid was $1.48 \mathrm{~g} / \mathrm{cm}^{3}$. There was not enough interstitial liquid to determine its viscosity.

The Tank $29 \mathrm{H}$ supernate sample (HTF-588A) had a density of $1.26 \mathrm{~g} / \mathrm{cm}^{3}$ with a standard deviation from four measurements of $0.02 \mathrm{~g} / \mathrm{cm}^{3}$. The samples had a total solids content (which is approximately all soluble solids) of $30.2 \mathrm{wt} \%$ with a standard deviation from three measurements of $0.4 \mathrm{wt} \%$.

\section{Chemical and Radiological Analyses}

Tables 3 through 6 contain the characterization information for the undrained bulk saltcake, interstitial liquid, and dip samples. Results are reported as the average of the individual analyses. Details of the analysis results, along with standard deviations, are shown in the appendix (Tables $10-14$ for undrained bulk saltcake from T29H-B6-1, Tables 15 - 18 for interstitial liquid drained from T29H-B6-1, and Tables $19-23$ for supernate sample HTF-588A). Values reported at less than their detection limits are preceded by " $<$ " and values that contain an average of detectable concentrations and detection limits are preceded by " $</="$.

The last column in Tables 3-5 shows the percentage of each component that is partitioned into the interstitial liquid Subtracting the "Partition into IL" from 100\% yields an estimate for each component of the percentage contained in the solid phase of the original saltcake sample. To calculate the "Partition into IL", the wt \% of the component measured in the filtered interstitial liquid (drained from T3F-1-4) is multiplied by the wt \% of IL in the undrained saltcake and divided by the wt $\%$ of the component measured in the undrained saltcake.

The portion of undrained saltcake that was analyzed contained a relatively large amount of aluminum (Al of $13.3 \mathrm{wt} \%)$ and a relatively small amount of sodium nitrate $\left(\mathrm{NaNO}_{3}\right.$ of $\left.7.4 \mathrm{wt} \%\right)$. The ${ }^{137} \mathrm{Cs}$ activity of the sample was $6.40 \mathrm{E}+8 \mathrm{pCi} / \mathrm{g}$, which corresponds to $5.2 \mathrm{Ci}$ per gallon of saltcake.

The total strontium in the undrained saltcake sample was calculated by adjusting the ICP-MS observation of ${ }^{88} \mathrm{Sr}$ and the radiochemistry observation of ${ }^{90} \mathrm{Sr}$. The total strontium in the Tank $29 \mathrm{H}$ sample was $5.35 \mathrm{E}-5 \mathrm{wt} \%$, of which ${ }^{90} \mathrm{Sr}$ had an $18.5 \mathrm{wt} \%$ isotopic contribution to the total strontium. 
WSRC-TR-2004-00130

Revision 0

The interstitial liquid had a ${ }^{137} \mathrm{Cs}$ activity of $1.69 \mathrm{E}+9 \mathrm{pCi} / \mathrm{g}(2.50 \mathrm{E}+9 \mathrm{pCi} / \mathrm{mL})$, which is $9.5 \mathrm{Ci}$ per gallon of IL. This ${ }^{137} \mathrm{Cs}$ content is significantly higher than the $4.6 \mathrm{Ci} / \mathrm{gal}$ expected from the average of Tank $29 \mathrm{H}$ supernate samples from 2001, but it is within the realm of expectations based on Tank $29 \mathrm{H}$ supernate samples from the mid 1980's through mid 1990's. ${ }^{5}$ The interstitial liquid also contained $38.1 \mathrm{mg} / \mathrm{L}$ of ${ }^{99} \mathrm{Tc}$, corresponding to $6.5 \mathrm{E}+5 \mathrm{pCi} / \mathrm{mL}$ of ${ }^{99} \mathrm{Tc}$.

The ${ }^{137} \mathrm{Cs}$ activity of the as-received supernate sample was $6.92 \mathrm{E}+8 \mathrm{pCi} / \mathrm{mL}$, which corresponds to 2.6 $\mathrm{Ci} / \mathrm{gal}$. The as-received sample contained $1.05 \mathrm{pCi} / \mathrm{g}(1.32 \mathrm{E}+5 \mathrm{pCi} / \mathrm{mL})$ of ${ }^{238} \mathrm{Pu}$, of which approximately $72 \%$ was removed upon filtration with a 0.45 -micron filter. Due to the uncertainty with these empirical data, it can not be concluded whether additional filtration with a 0.1-micron filter provided additional removal of actinide components.

Table 3: Saltcake, Interstitial liquid, and Dip Sample Radiological Analysis Comparison

\begin{tabular}{|c|c|c|c|c|c|c|c|}
\hline & & \multicolumn{2}{|c|}{ T29H-B6-1 } & \multicolumn{3}{|c|}{ Tk 29 Dip (HTF-588A) } & \multirow[b]{2}{*}{ PIL } \\
\hline & & $\begin{array}{l}\text { Undrained } \\
\text { saltcake }\end{array}$ & $\begin{array}{l}\text { Interstitial } \\
\text { liquid }\end{array}$ & $\begin{array}{l}\text { Unfiltered } \\
\text { Supernate }\end{array}$ & $\begin{array}{l}\text { Filtered } \\
(0.45 \mu \mathrm{m}) \\
\text { Supernate }\end{array}$ & $\begin{array}{l}\text { Filtered } \\
(0.1 \mu \mathrm{m}) \\
\text { Supernate }\end{array}$ & \\
\hline Analyte & Units & Average & Average & Average & Average & Average & $\%$ \\
\hline${ }^{14} \mathrm{C}$ & $(\mathrm{pCi} / g)$ & $9.9 \mathrm{E}+02$ & -- & -- & $1.20 \mathrm{E}+03$ & -- & -- \\
\hline${ }^{90} \mathrm{Sr}$ & $(\mathrm{pCi} / \mathrm{g})$ & $1.35 \mathrm{E}+07$ & $1.14 \mathrm{E}+06$ & $1.14 \mathrm{E}+04$ & $1.26 \mathrm{E}+05$ & $9.64 \mathrm{E}+04$ & 3.3 \\
\hline${ }^{99} \mathrm{Tc}$ & $(\mathrm{pCi} / \mathrm{g})$ & $2.01 \mathrm{E}+05$ & $4.36 \mathrm{E}+05$ & $1.40 \mathrm{E}+05$ & $1.45 E+05$ & $1.38 \mathrm{E}+05$ & 84.7 \\
\hline${ }^{135} \mathrm{Cs}$ & $(\mathrm{pCi} / \mathrm{g})$ & $2.76 \mathrm{E}+03$ & $6.55 E+03$ & $2.18 \mathrm{E}+03$ & $2.25 E+03$ & $2.15 E+03$ & 92.7 \\
\hline${ }^{137} \mathrm{Cs}$ & $(\mathrm{pCi} / \mathrm{g})$ & $6.40 \mathrm{E}+08$ & $1.69 \mathrm{E}+09$ & $5.50 \mathrm{E}+08$ & $5.68 \mathrm{E}+08$ & $5.72 \mathrm{E}+08$ & 103.3 \\
\hline${ }^{230} \mathrm{Th}$ & $(\mathrm{pCi} / \mathrm{g})$ & $<5.7 \mathrm{E}+02$ & $<6.8 \mathrm{E}+02$ & $<1.3 \mathrm{E}+03$ & $<1.3 \mathrm{E}+03$ & $<1.2 \mathrm{E}+03$ & -- \\
\hline${ }^{232} \mathrm{Th}$ & $(\mathrm{pCi} / \mathrm{g})$ & $6.23 \mathrm{E}-02$ & $<3.7 \mathrm{E}-03$ & $<7.2 \mathrm{E}-03$ & $<7.2 \mathrm{E}-03$ & $<6.4 \mathrm{E}-03$ & $<2.3$ \\
\hline${ }^{233} U$ & $(\mathrm{pCi} / \mathrm{g})$ & $1.89 \mathrm{E}+03$ & $<3.3 \mathrm{E}+02$ & $<6.4 \mathrm{E}+02$ & $<6.3 \mathrm{E}+02$ & $<5.7 \mathrm{E}+02$ & $<6.7$ \\
\hline${ }^{234} U$ & $(\mathrm{pCi} / \mathrm{g})$ & $2.43 E+03$ & $<2.1 \mathrm{E}+02$ & $<4.1 \mathrm{E}+02$ & $<4.1 \mathrm{E}+02$ & $<3.7 \mathrm{E}+02$ & $<3.4$ \\
\hline${ }^{235} \mathrm{U}$ & $(\mathrm{pCi} / \mathrm{g})$ & $6.62 \mathrm{E}+00$ & 1.59E-01 & 3.96E-01 & $2.51 \mathrm{E}-01$ & $2.29 \mathrm{E}-01$ & 0.9 \\
\hline${ }^{236} \mathrm{U}$ & $(\mathrm{pCi} / \mathrm{g})$ & $8.91 \mathrm{E}+01$ & $2.66 \mathrm{E}+00$ & $4.54 \mathrm{E}+00$ & $<4.2 \mathrm{E}+00$ & $<3.8 \mathrm{E}+00$ & 1.2 \\
\hline${ }^{237} \mathrm{~Np}$ & $(\mathrm{pCi} / \mathrm{g})$ & $7.46 \mathrm{E}+01$ & $<2.4 \mathrm{E}+01$ & $<4.6 \mathrm{E}+01$ & $<4.6 \mathrm{E}+01$ & $<4.1 \mathrm{E}+01$ & 12.4 \\
\hline${ }^{238} \mathrm{U}$ & $(\mathrm{pCi} / \mathrm{g})$ & $4.95 \mathrm{E}+00$ & 9.43E-01 & 4.47E-01 & $3.54 \mathrm{E}-01$ & 3.03E-01 & 7.5 \\
\hline${ }^{238} \mathrm{Pu}$ & $(\mathrm{pCi} / \mathrm{g})$ & $1.12 E+06$ & $7.61 \mathrm{E}+03$ & $1.05 E+05$ & $2.90 \mathrm{E}+04$ & $2.70 E+04$ & 0.3 \\
\hline${ }^{239 / 240} \mathrm{Pu}$ & $(\mathrm{pCi} / \mathrm{g})$ & $1.79 \mathrm{E}+04$ & $2.13 E+03$ & $2.11 \mathrm{E}+03$ & $8.76 \mathrm{E}+02$ & $<6.60 \mathrm{E}+02$ & 4.7 \\
\hline${ }^{239} \mathrm{Pu}$ & $(\mathrm{pCi} / \mathrm{g})$ & $9.53 E+03$ & $<2.1 \mathrm{E}+03$ & $<4.1 \mathrm{E}+03$ & $<4.1 \mathrm{E}+03$ & $<3.6 \mathrm{E}+03$ & $<8.6$ \\
\hline${ }^{240} \mathrm{Pu}$ & $(\mathrm{pCi} / \mathrm{g})$ & $<6.4 \mathrm{E}+03$ & $<7.6 \mathrm{E}+03$ & $<1.5 \mathrm{E}+04$ & $<1.5 \mathrm{E}+04$ & $<1.3 \mathrm{E}+04$ & -- \\
\hline${ }^{241} \mathrm{Pu}$ & $(\mathrm{pCi} / \mathrm{g})$ & $<2.9 \mathrm{E}+06$ & $<3.5 \mathrm{E}+06$ & $<6.8 \mathrm{E}+06$ & $<6.7 \mathrm{E}+06$ & $<6.0 \mathrm{E}+06$ & -- \\
\hline${ }^{241} \mathrm{Am}$ & $(\mathrm{pCi} / \mathrm{g})$ & $1.13 E+04$ & $1.82 E+03$ & $<5.00 \mathrm{E}+02$ & $<5.43 \mathrm{E}+02$ & $<3.83 \mathrm{E}+02$ & 6.3 \\
\hline${ }^{242} \mathrm{Pu}$ & $(\mathrm{pCi} / \mathrm{g})$ & $<1.1 \mathrm{E}+02$ & $<1.3 \mathrm{E}+02$ & $<2.6 \mathrm{E}+02$ & $<2.6 \mathrm{E}+02$ & $<2.3 \mathrm{E}+02$ & -- \\
\hline Total U & $\mathrm{wt} \%$ & 2.0E-03 & $<3.0 \mathrm{E}-04$ & -- & -- & -- & -- \\
\hline $\begin{array}{l}\text { U-235 } \\
\text { enrichment }\end{array}$ & $w t \%$ & 1.6E+01 & $2.47 E+00$ & -- & -- & -- & -- \\
\hline
\end{tabular}


Table 4: Saltcake, Interstitial liquid, and Dip Sample Principal Component Comparison

\begin{tabular}{|c|c|c|c|c|c|}
\hline \multirow[b]{2}{*}{ Analyte } & & \multicolumn{2}{|c|}{ T29H-B6-1 } & Tk 29 Dip & \\
\hline & & $\begin{array}{l}\text { Undrained } \\
\text { saltcake }\end{array}$ & $\begin{array}{l}\text { Interstitial } \\
\text { liquid }\end{array}$ & $\begin{array}{l}\text { Filtered } \\
(0.45 \mu \mathrm{m}) \\
\text { Supernate }\end{array}$ & \\
\hline & Units & Average & Average & Average & PIL \% \\
\hline $\mathrm{Na}^{+}$ & $w t \%$ & $2.13 \mathrm{E}+01$ & $1.83 \mathrm{E}+01$ & $9.98 \mathrm{E}+00$ & 33.7 \\
\hline $\mathrm{NO}_{3}{ }^{-}$ & wt $\%$ & $5.38 E+00$ & 7.71E+00 & $8.30 E+00$ & 56.1 \\
\hline $\mathrm{NO}_{2}^{-}$ & wt $\%$ & $3.03 E+00$ & $8.25 E+00$ & 2.57E+00 & 106.6 \\
\hline $\mathrm{SO}_{4}{ }^{2-}$ & wt $\%$ & $2.19 \mathrm{E}+00$ & 4.40E-02 & 5.36E-01 & 0.8 \\
\hline $\mathrm{PO}_{4}{ }^{3-}$ & wt $\%$ & 7.91E-02 & $2.96 \mathrm{E}-01$ & $3.10 \mathrm{E}-02$ & 146.5 \\
\hline $\mathrm{Cl}^{-}$ & wt $\%$ & 2.02E-01 & $</=1.22 \mathrm{E}-02$ & 4.77E-03 & $<2.4$ \\
\hline $\mathrm{F}^{-}$ & wt $\%$ & $<9.68 \mathrm{E}-03$ & $<9.79 E-03$ & 1.43E-03 & -- \\
\hline $\mathrm{C}_{2} \mathrm{O}_{4}{ }^{2-}$ & wt $\%$ & $<4.84 \mathrm{E}-02$ & $<4.89 E-02$ & 7.15E-03 & -- \\
\hline $\mathrm{CHO}_{2}^{-}$ & wt $\%$ & $<4.84 \mathrm{E}-02$ & $<4.89 E-02$ & $<4.8 \mathrm{E}-02$ & -- \\
\hline Free $\mathrm{OH}-$ & wt $\%$ & $7.71 \mathrm{E}+00$ & $5.32 \mathrm{E}+00$ & $2.04 \mathrm{E}+00$ & 27.0 \\
\hline $\mathrm{AlO}_{2}^{-}$ & wt $\%$ & $2.9 \mathrm{E}+01$ & $3.84 \mathrm{E}+00$ & $1.47 \mathrm{E}+00$ & 5.2 \\
\hline $\mathrm{CO}_{3}{ }^{2-}$ & wt $\%$ & $3.02 E+00$ & $8.48 \mathrm{E}-01$ & $1.88 \mathrm{E}+00$ & 11.0 \\
\hline $\mathrm{K}^{+}$ & wt $\%$ & 8.06E-02 & 2.95E-01 & $<7.66 \mathrm{E}-02$ & 143.3 \\
\hline TOC & wt $\%$ & 3.9E-01 & $2.55 \mathrm{E}-01$ & 3.00E-01 & 25.5 \\
\hline Total Base & $w t \%$ as $\mathrm{OH}^{-}$ & $1.49 \mathrm{E}+01$ & $9.90 E+00$ & & 25.9 \\
\hline Mass Balance & & 94.0 & -- & 97.0 & \\
\hline Charge balance & $\%$ (cation-anion) & -35.3 & 10.6 & 6.1 & \\
\hline wt $\%$ solid & calculated wt $\%$ & $7.26 \mathrm{E}+01$ & $4.53 E+01$ & $2.72 \mathrm{E}+01$ & \\
\hline wt $\%$ water & calculated wt $\%$ & $2.74 \mathrm{E}+01$ & $5.47 \mathrm{E}+01$ & $7.28 \mathrm{E}+01$ & \\
\hline
\end{tabular}


WSRC-TR-2004-00130

Revision 0

Table 5: Saltcake, Interstitial liquid, and Dip Sample Elemental Comparison

\begin{tabular}{|c|c|c|c|c|c|c|c|}
\hline & & \multicolumn{2}{|c|}{$\mathrm{T} 29 \mathrm{H}-\mathrm{B} 6-1$} & \multicolumn{3}{|c|}{ Tk 29 Dip (HTF-588A) } & \\
\hline & & $\begin{array}{l}\text { Undrained } \\
\text { saltcake }\end{array}$ & $\begin{array}{l}\text { Interstitial } \\
\text { liquid }\end{array}$ & $\begin{array}{l}\text { Unfiltered } \\
\text { Supernate }\end{array}$ & $\begin{array}{l}\text { Filtered }(0.45 \\
\mu \mathrm{m}) \\
\text { Supernate }\end{array}$ & $\begin{array}{l}\text { Filtered }(0.1 \\
\mu \mathrm{m}) \\
\text { Supernate }\end{array}$ & \\
\hline Analyte & Units & Average & Average & Average & Average & Average & PIL \% \\
\hline $\mathrm{Ag}$ & wt \% & $<6.94 \mathrm{E}-04$ & $<7.81 \mathrm{E}-05$ & $<7.35 \mathrm{E}-04$ & $<7.33 \mathrm{E}-04$ & $<6.53 \mathrm{E}-04$ & -- \\
\hline $\mathrm{Al}$ & wt \% & $1.33 \mathrm{E}+01$ & $1.76 \mathrm{E}+00$ & $1.98 \mathrm{E}-01$ & $6.73 \mathrm{E}-01$ & $5.11 \mathrm{E}-01$ & 5.2 \\
\hline$B$ & wt $\%$ & $<7.50 \mathrm{E}-02$ & 1.02E-02 & $<7.94 \mathrm{E}-02$ & $<7.91 \mathrm{E}-02$ & $<7.06 \mathrm{E}-02$ & -- \\
\hline $\mathrm{Ba}$ & wt $\%$ & $<6.94 \mathrm{E}-04$ & $2.64 \mathrm{E}-04$ & $<7.35 \mathrm{E}-04$ & $<7.33 \mathrm{E}-04$ & $<6.53 \mathrm{E}-04$ & -- \\
\hline $\mathrm{Ca}$ & wt $\%$ & $<2.10 \mathrm{E}-02$ & $<2.29 \mathrm{E}-03$ & $<2.22 \mathrm{E}-02$ & $<2.21 \mathrm{E}-02$ & $<1.97 \mathrm{E}-02$ & -- \\
\hline $\mathrm{Cd}$ & wt $\%$ & $<9.25 \mathrm{E}-04$ & $<1.01 \mathrm{E}-04$ & $<9.80 \mathrm{E}-04$ & $<9.77 \mathrm{E}-04$ & $<8.71 \mathrm{E}-04$ & -- \\
\hline $\mathrm{Ce}$ & wt $\%$ & $<1.15 \mathrm{E}-02$ & $<1.25 \mathrm{E}-03$ & $<1.22 \mathrm{E}-02$ & $<1.21 \mathrm{E}-02$ & $<1.08 \mathrm{E}-02$ & -- \\
\hline $\mathrm{Cr}$ & wt \% & $2.13 \mathrm{E}-02$ & 2.96E-02 & $6.45 \mathrm{E}-03$ & 1.02E-02 & $8.58 \mathrm{E}-03$ & 54.5 \\
\hline $\mathrm{Cu}$ & wt \% & $<1.44 \mathrm{E}-03$ & $2.03 E-03$ & $<1.52 \mathrm{E}-03$ & $<1.51 \mathrm{E}-03$ & $<1.35 \mathrm{E}-03$ & -- \\
\hline $\mathrm{Fe}$ & wt \% & 1.08E-02 & 1.17E-02 & $<1.08 \mathrm{E}-03$ & $<1.07 \mathrm{E}-03$ & $<9.58 \mathrm{E}-04$ & 42.6 \\
\hline Gd & wt $\%$ & $<1.25 \mathrm{E}-03$ & $<1.38 \mathrm{E}-04$ & $<1.32 \mathrm{E}-03$ & $<1.32 \mathrm{E}-03$ & $<1.18 \mathrm{E}-03$ & -- \\
\hline $\mathrm{K}$ & wt \% & $<4.41 \mathrm{E}-01$ & 2.95E-01 & $<4.67 \mathrm{E}-01$ & $<4.65 \mathrm{E}-01$ & $<4.15 \mathrm{E}-01$ & -- \\
\hline La & wt $\%$ & $<9.25 \mathrm{E}-04$ & $</=1.1 \mathrm{E}-04$ & $<9.80$ E-04 & $<9.77 \mathrm{E}-04$ & $<8.71 \mathrm{E}-04$ & -- \\
\hline $\mathrm{Li}$ & wt $\%$ & $<3.94 \mathrm{E}-03$ & $6.00 \mathrm{E}-03$ & $<4.16 \mathrm{E}-03$ & $<4.15 \mathrm{E}-03$ & $<3.70 \mathrm{E}-03$ & -- \\
\hline $\mathrm{Mg}$ & wt $\%$ & $</=3.99 E-03$ & 1.31E-03 & $<3.04 \mathrm{E}-03$ & $<3.03 \mathrm{E}-03$ & $<2.70$ E-03 & -- \\
\hline $\mathrm{Mn}$ & wt $\%$ & $</=2.20 \mathrm{E}-03$ & 2.86E-03 & $<1.08 \mathrm{E}-03$ & $<1.07 \mathrm{E}-03$ & $<9.58 \mathrm{E}-04$ & -- \\
\hline Mo & wt $\%$ & 1.97E-02 & 2.65E-02 & $<1.00 \mathrm{E}-02$ & $<9.97 \mathrm{E}-03$ & 9.13E-03 & 52.5 \\
\hline $\mathrm{Na}$ & wt $\%$ & $2.13 \mathrm{E}+01$ & $1.83 \mathrm{E}+01$ & $8.91 \mathrm{E}+00$ & $9.98 \mathrm{E}+00$ & $9.17 \mathrm{E}+00$ & 33.7 \\
\hline $\mathrm{Ni}$ & wt \% & $<3.47 \mathrm{E}-03$ & $1.2 \mathrm{E}-03$ & $<3.67 \mathrm{E}-03$ & $<3.66 \mathrm{E}-03$ & $<3.27 \mathrm{E}-03$ & -- \\
\hline$P$ & wt $\%$ & 4.45E-02 & 1.03E-01 & $<2.38 \mathrm{E}-02$ & $<2.37 \mathrm{E}-02$ & $</=2.12 \mathrm{E}-02$ & 90.5 \\
\hline $\mathrm{Pb}$ & wt $\%$ & $<1.14 \mathrm{E}-02$ & $<1.25 \mathrm{E}-03$ & $<1.21 \mathrm{E}-02$ & $<1.20 \mathrm{E}-02$ & $<1.07 \mathrm{E}-02$ & -- \\
\hline$S$ & wt \% & 6.67E-01 & $7.38 \mathrm{E}-02$ & 1.95E-01 & 1.33E-01 & 1.91E-01 & 4.3 \\
\hline $\mathrm{Sb}$ & wt $\%$ & 3.67E-02 & $5.35 \mathrm{E}-03$ & $<7.40 \mathrm{E}-03$ & $<7.38 \mathrm{E}-03$ & $<6.58 \mathrm{E}-03$ & 5.7 \\
\hline $\mathrm{Si}$ & wt \% & $2.24 \mathrm{E}-02$ & 1.77E-02 & 6.86E-02 & $6.50 \mathrm{E}-02$ & $5.38 \mathrm{E}-02$ & 30.9 \\
\hline $\mathrm{Sn}$ & wt $\%$ & 1.30E-02 & 2.79E-03 & $<1.20 \mathrm{E}-02$ & $<1.20 \mathrm{E}-02$ & $<1.07 \mathrm{E}-02$ & 8.4 \\
\hline $\mathrm{Sr}$ & wt \% & $<4.63 \mathrm{E}-03$ & $<5.06 \mathrm{E}-04$ & $<4.90 \mathrm{E}-03$ & $<4.89 \mathrm{E}-03$ & $<4.36 \mathrm{E}-03$ & -- \\
\hline $\mathrm{Ti}$ & wt $\%$ & $<2.78 \mathrm{E}-04$ & $<3.22 \mathrm{E}-05$ & $<2.94 \mathrm{E}-04$ & $<2.93 \mathrm{E}-04$ & $<2.61 \mathrm{E}-04$ & -- \\
\hline $\mathrm{Zn}$ & wt $\%$ & $<2.55 \mathrm{E}-03$ & $4.18 \mathrm{E}-03$ & $<2.69 \mathrm{E}-03$ & $<2.69 \mathrm{E}-03$ & $<2.40 \mathrm{E}-03$ & -- \\
\hline $\mathrm{Zr}$ & wt \% & $<5.56 \mathrm{E}-04$ & 1.1E-04 & $<5.88 \mathrm{E}-04$ & $<5.86 \mathrm{E}-04$ & $<5.23 \mathrm{E}-04$ & -- \\
\hline
\end{tabular}

Table 6: Likely major components of dry Tank $29 \mathrm{H}$ salt solids, normalized

\begin{tabular}{|l|r|}
\hline Species & $\begin{array}{c}\text { estim. } \\
\text { wt\% }\end{array}$ \\
\hline $\mathrm{NaNO}_{3}$ & 2.26 \\
\hline $\mathrm{Na}_{2} \mathrm{SO}_{4}$ & 4.98 \\
\hline $\mathrm{NaCl}$ & 0.50 \\
\hline $\mathrm{NaF}$ & 0.01 \\
\hline $\mathrm{Na}_{2} \mathrm{C}_{2} \mathrm{O}_{4}$ & 0.05 \\
\hline $\mathrm{NaCHO}_{2}$ & 0.04 \\
\hline $\mathrm{NaAlO}_{2} \cdot 2 \mathrm{H}_{2} \mathrm{O}$ & 83.95 \\
\hline $\mathrm{Na}_{2} \mathrm{CO}_{3} \cdot \mathrm{H}_{2} \mathrm{O}$ & 8.20 \\
\hline
\end{tabular}




\section{Dissolution of Drained Saltcake}

Approximately $46.3 \mathrm{~g}$ of salt was removed from the bottom of the top half of T29H-B6-1-A for as-received characterization, leaving about $112.2 \mathrm{~g}(52.7 \mathrm{~mL}$, calculated) of undrained saltcake in the top half of $\mathrm{T} 29 \mathrm{H}-\mathrm{B} 6-1-\mathrm{A}$. The remaining salt was drained under 10 inches $\mathrm{Hg}$ vacuum for 6.8 days, removing $13.3 \mathrm{~g}$ of interstitial liquid. At the conclusion of this draining (and the start of the dissolution test), approximately $98.9 \mathrm{~g}$ of drained saltcake remained in T29H-B6-1-A.

As water was added during dissolution, only several drops of effluent emerged from the sample initially. Vacuum was applied to the bottom of the apparatus to force liquid to flow through the sample. Only $5 \mathrm{~mL}$ was removed during the remaining 6 hours of the first dissolution shift, which became the first subsample. The following day, water was again applied to the sample while vacuum was used to assist flow through the sample. After 2 hours, a $61 \mathrm{~mL}$ slug of liquid and solids suddenly emerged from the bottom of the sample and was collected. At this time, the vacuum was stopped and a $5 \mathrm{~mL}$ portion of the liquid and solids became the second sub-sample. The remaining $56 \mathrm{~mL}$ of the material that was pulled through the sample became the beginning of the bulk dissolved salt effluent. When water was reapplied to the saltcake, the remainder of the dissolution proceeded without assistance of vacuum. The effluent did not reach the target density of $1.3 \mathrm{~g} / \mathrm{mL}$, likely due to the relatively fast water addition rate $(\sim 9 \mathrm{~mL} / \mathrm{min})$ and the possible channeling through the sample. Salt was completely removed from the sample during the test.

Tables 7 through 9 contain the $\mathrm{T} 29 \mathrm{H}-\mathrm{B} 6-1$ dissolution information and analysis of the unfiltered subsamples and filtered bulk dissolved salt effluent. The anion-cation balance is in poor agreement for the second sub-sample and the density of the second sub-sample is estimated from the sodium concentration. The ${ }^{137} \mathrm{Cs}$ content of the first sub-sample was $9.0 \mathrm{Ci} / \mathrm{gal}$ at $11.5 \mathrm{M} \mathrm{Na}^{+}$, indicating that the first $5 \mathrm{~mL}$ of effluent vacuum extracted was essentially the same as the original interstitial liquid. Although the Tank $29 \mathrm{H}$ test did not run smoothly, as expected, the ${ }^{137} \mathrm{Cs}$ concentration of subsequent sub-samples again declined more quickly than the $\mathrm{Na}^{+}$. The bulk dissolved salt effluent had $\mathrm{a}^{137} \mathrm{Cs}$ of $0.32 \mathrm{Ci} / \mathrm{gal}$ at 3.5 $\mathrm{M} \mathrm{Na}^{+}$. The ${ }^{238} \mathrm{Pu}$ content of the filtered bulk salt effluent was less than the ${ }^{238} \mathrm{Pu}$ content of the unfiltered sub-samples, indicating that ${ }^{238} \mathrm{Pu}$ can be removed by filtration (although it was not proven that the Pu was at thermodynamic equilibrium when filtered). The total alpha content of the filtered bulk salt effluent was $<2 \mathrm{nCi} / \mathrm{mL}$.

Figure 8 contains a photo of the four sub-samples (glass graduated bottles in foreground, ordered left to right) and the bulk salt effluent (larger polyethylene bottle) collected during the dissolution of the top half of T29H-B6-1. The insoluble solids were not re-suspended before the photo was taken. The second subsample, corresponding to a portion of the slug of material that broke through the saltcake, contained 30 to 50 vol. \% of white insoluble solids. The bulk sample contained about $40 \mathrm{~mL}$ of insoluble solids in the 220 $\mathrm{mL}$ sample. The solids were not included in the analysis of that liquid.

Figure 9 contains the XRD analysis of the insoluble solids filtered from the Tank $29 \mathrm{H}$ bulk dissolved salt effluent. The only crystalline material identified in the insoluble solids was the aluminum hydroxide $\left(\mathrm{Al}(\mathrm{OH})_{3}\right)$ polymorphs: gibbsite and bayerite. From the estimated composition of the saltcake, these materials may have been present initially, but more likely formed from disproportionation of sodium aluminate. The fine particulate aluminum hydroxide likely built up at the top of the saltcake during dissolution, prohibiting the water from contacting additional salt. This phenomenon was noted by Mississippi State University DIAL during similar dissolution testing of Hanford high-aluminum saltcake simulant.

Figures 10 and 11 contain plots of the analysis of selected components during the dissolution tests. Because of the difficulty with dissolution in the second step, the results are not representative of a fully saturated solution and may not be in thermodynamic equilibrium with the saltcake. The cation-anion balance indicates a problem with the analysis or sample preparation. 
WSRC-TR-2004-00130

Revision 0

Figures 12 and 13 contain two views from the Scanning Electron Microscope photograph of the insoluble solids remaining from the dissolution test, and the Energy Dispersive Spectra (X-ray) analysis of the first photograph is shown in Figure 14. The solids appear homogeneous, but not very crystalline. The minimal amount of sodium present indicates that the solids are almost entirely aluminum hydroxide or oxides. The particle size is not easily discernible from these photographs. Although a bulky particle is shown in Figure 12 that is $30+$ microns across, it appears to be a conglomeration of submicron-sized particles. Figure 13 indicates suggests particles that are 2-3 microns in diameter, but the photo does not exhibit discreet particles.

Table 7: Tank $29 \mathrm{H}$ drained saltcake dissolution information and analysis of dissolved saltcake for radiochemical and ionic components.

\begin{tabular}{|c|c|c|c|c|c|c|}
\hline $\begin{array}{l}\text { Sample T29H- } \\
\text { B6-1 }\end{array}$ & $1^{\text {st }}$ & $2^{\text {nd }}$ & $3^{\text {rd }}$ & $4^{\text {th }}$ & \multicolumn{2}{|c|}{ Filtered Bulk } \\
\hline Time (min) & 0 to 360 & 360 to 480 & 488 to 489 & 502 to 503 & \multicolumn{2}{|c|}{0 to 503} \\
\hline $\begin{array}{l}\text { Flow Rate } \\
(\mathrm{mL} / \mathrm{min})\end{array}$ & $\mathrm{N} / \mathrm{A}$ & $\mathrm{N} / \mathrm{A}$ & 9.0 & $\mathrm{~N} / \mathrm{A}$ & \multicolumn{2}{|l|}{--} \\
\hline Volume $(\mathrm{mL})$ & 0.0 to 5.0 & 5.0 to 66 & 116 to 121 & 181 to 186 & \multicolumn{2}{|c|}{0 to 216} \\
\hline Density $(\mathrm{g} / \mathrm{mL})$ & 1.43 & $1.3^{*}$ & 1.18 & 1.07 & \multicolumn{2}{|c|}{1.12} \\
\hline \multicolumn{5}{|c|}{ Radioisotopic Composition (pCi/mL) } & avg. & st.dev. \\
\hline${ }^{90} \mathrm{Sr}$ & -- & -- & -- & -- & $7.37 E+03$ & $1.0 \mathrm{E}+03$ \\
\hline${ }^{99}$ Tc minimum & -- & -- & -- & -- & $2.03 E+04$ & $1.0 \mathrm{E}+03$ \\
\hline${ }^{99} \mathrm{Tc}$ maximum & -- & -- & - & -- & $2.10 \mathrm{E}+04$ & $1.1 \mathrm{E}+03$ \\
\hline${ }^{137} \mathrm{Cs}$ & $2.38 \mathrm{E}+09$ & $4.37 \mathrm{E}+07$ & $1.11 \mathrm{E}+07$ & $3.55 \mathrm{E}+06$ & $8.40 \mathrm{E}+07$ & $1 \mathrm{E}+06$ \\
\hline${ }^{238} \mathrm{Pu}$ & $2.21 \mathrm{E}+04$ & $1.24 \mathrm{E}+03$ & $2.39 E+04$ & $1.82 \mathrm{E}+03$ & $<7.02 E+02$ & -- \\
\hline${ }^{239 / 240} \mathrm{Pu}$ & $6.83 E+02$ & $<4.45 E+02$ & $6.69 E+02$ & $<3.55 E+02$ & $<1.08 E+03$ & -- \\
\hline${ }^{241} \mathrm{Am}$ & -- & -- & -- & -- & $<2.26 E+02$ & -- \\
\hline \multicolumn{5}{|c|}{ Ionic Composition (M) } & avg. & st.dev. \\
\hline $\mathrm{Na}^{+}$ & $1.15 E+01$ & $5.99 \mathrm{E}+00$ & $2.09 E+00$ & $1.62 \mathrm{E}+00$ & $3.48 \mathrm{E}+00$ & $5 \mathrm{E}-02$ \\
\hline $\mathrm{NO}_{3}^{-}$ & $1.15 E+00$ & 2.81E-02 & $9.23 E-02$ & 1.99E-02 & 3.90E-01 & 4E-03 \\
\hline $\mathrm{NO}_{2}^{-}$ & $1.60 \mathrm{E}+00$ & $1.47 \mathrm{E}-02$ & 5.64E-02 & $5.38 \mathrm{E}-03$ & 8.42E-02 & $1 \mathrm{E}-03$ \\
\hline $\mathrm{OH}^{-}$ & $3.17 E+00$ & 4.23E-01 & $9.78 \mathrm{E}-01$ & $2.42 \mathrm{E}-01$ & 8.66E-01 & $1.65 \mathrm{E}-01$ \\
\hline $\mathrm{AlO}_{2}^{-}$ & $1.01 \mathrm{E}+00$ & $7.52 \mathrm{E}-01$ & 3.49E-01 & $1.68 \mathrm{E}-01$ & $4.25 \mathrm{E}-01$ & 1E-03 \\
\hline $\mathrm{CO}_{3}{ }^{2-}$ & $8.24 \mathrm{E}-02$ & $2.21 \mathrm{E}-01$ & $7.45 \mathrm{E}-01$ & $3.25 \mathrm{E}-01$ & $4.91 \mathrm{E}-01$ & 3.3E-02 \\
\hline $\mathrm{SO}_{4}{ }^{2-}$ & 1.43E-02 & 5.33E-02 & 1.69E-01 & $5.15 \mathrm{E}-02$ & 9.53E-02 & 2.6E-03 \\
\hline $\mathrm{PO}_{4}{ }^{3-}$ & $2.42 \mathrm{E}-02$ & 5.09E-04 & $<1.03 E-03$ & $<5.21 E-04$ & 1.45E-03 & 5.9E-04 \\
\hline $\mathrm{Cl}^{-}$ & 4.14E-03 & $<2.73 E-04$ & $<2.76 E-04$ & $<2.79 E-04$ & $<1.11 E-03$ & -- \\
\hline $\mathrm{F}^{-}$ & $<5.16 E-03$ & $<5.09 E-04$ & 5.15E-04 & $<5.21 E-04$ & $<2.08 E-03$ & -- \\
\hline $\mathrm{C}_{2} \mathrm{O}_{4}{ }^{2-}$ & $<5.56 E-03$ & $<5.49 E-04$ & 5.56E-04 & $<5.62 E-04$ & $<4.48 E-04$ & -- \\
\hline $\mathrm{CHO}_{2}^{-}$ & $<1.09 E-02$ & $<1.07 E-03$ & $<1.09 E-03$ & $<1.10 E-03$ & $<4.38 E-03$ & -- \\
\hline Total Base & $5.09 \mathrm{E}+00$ & $1.63 E+00$ & $3.59 \mathrm{E}+00$ & 6.43E-01 & $2.68 \mathrm{E}+00$ & 1.1E-01 \\
\hline $\mathrm{K}^{+}$ & $<1.73 E-01$ & $<1.57 E-01$ & $<2.14 E-01$ & $<1.30 E-01$ & 2.93E-03 & 1.9E-04 \\
\hline
\end{tabular}

N/A: Not Applicable. The flow rates in some cases could not be determined due to their irregular rates or the presence of solids. 
Table 8: Other Elemental Analysis of the Dissolution of Drained Tank 29H Saltcake

\begin{tabular}{|c|c|c|c|c|c|c|}
\hline $\begin{array}{l}\text { Sample T29H- } \\
\text { B6-1 }\end{array}$ & $1^{\text {st }}$ & $2^{\text {nd }}$ & $3^{\text {rd }}$ & $4^{\text {th }}$ & \multicolumn{2}{|c|}{ Filtered Bulk } \\
\hline \multicolumn{5}{|c|}{ Other Elemental Composition (mg/L) } & avg. & st.dev. \\
\hline $\mathrm{Ag}$ & $<1.06 E+01$ & $<9.65 E+00$ & $<1.32 E+01$ & $<7.99 E+00$ & $<3.33 E+00$ & -- \\
\hline As & -- & -- & -- & -- & $<1.11 \mathrm{E}+00$ & -- \\
\hline B & $<1.15 E+03$ & $<1.04 E+03$ & $<1.43 E+03$ & $<8.64 E+02$ & $<3.60 E+02$ & -- \\
\hline $\mathrm{Ba}$ & $1.27 \mathrm{E}+01$ & $<9.65 E+00$ & $<1.32 E+01$ & $<7.99 E+00$ & $<3.33 E+00$ & -- \\
\hline $\mathrm{Ca}$ & $<3.22 E+02$ & $<2.91 E+02$ & $<3.98 E+02$ & $<2.41 E+02$ & $<1.00 E+02$ & -- \\
\hline $\mathrm{Cd}$ & $<1.42 E+01$ & $<1.29 E+01$ & $<1.76 E+01$ & $<1.07 E+01$ & $<4.44 E+00$ & -- \\
\hline $\mathrm{Ce}$ & $<1.76 E+02$ & $1.60 \mathrm{E}+02$ & $2.18 \mathrm{E}+02$ & $1.32 \mathrm{E}+02$ & $<5.50 E+01$ & -- \\
\hline Co & -- & -- & -- & -- & $<1.85 E-01$ & -- \\
\hline $\mathrm{Cr}$ & $4.58 \mathrm{E}+02$ & $<1.09 E+01$ & $<1.50 E+01$ & $<9.07 E+00$ & $1.75 E+01$ & 3.96E-01 \\
\hline Cs & -- & -- & -- & -- & $2.63 E+00$ & \\
\hline $\mathrm{Cu}$ & $4.24 \mathrm{E}+01$ & $<1.99 E+01$ & $<2.72 E+01$ & $<1.65 E+01$ & $<6.88 E+00$ & -- \\
\hline $\mathrm{Fe}$ & $3.02 E+01$ & $<1.42 E+01$ & $<1.93 E+01$ & $<1.17 E+01$ & $<4.88 E+00$ & -- \\
\hline $\mathrm{Gd}$ & $<1.92 E+01$ & $<1.74 E+01$ & $<2.37 E+01$ & $<1.44 E+01$ & $<5.99 E+00$ & -- \\
\hline $\mathrm{Hg}$ & -- & -- & -- & -- & $<2.44 \mathrm{E}+00$ & -- \\
\hline La & $<1.42 E+01$ & $<1.29 E+01$ & $<1.76 E+01$ & $<1.07 E+01$ & $<4.44 E+00$ & -- \\
\hline $\mathrm{Li}$ & $<6.04 E+01$ & $<5.46 E+01$ & $<7.47 E+01$ & $<4.53 E+01$ & $<1.88 E+01$ & -- \\
\hline $\mathrm{Mg}$ & $<4.41 E+01$ & $<3.99 E+01$ & $<5.46 E+01$ & $<3.30 E+01$ & $<1.38 E+01$ & -- \\
\hline $\mathrm{Mn}$ & $<1.56 E+01$ & $<1.42 E+01$ & $<1.93 E+01$ & $<1.17 E+01$ & $<4.88 E+00$ & -- \\
\hline Mo & $3.61 \mathrm{E}+02$ & $<1.31 E+02$ & $<1.79 E+02$ & $<1.08 E+02$ & $<4.52 E+01$ & -- \\
\hline $\mathrm{Ni}$ & $<5.32 E+01$ & $<4.82 E+01$ & $<6.60 E+01$ & $<4.00 E+01$ & $<1.66 E+01$ & -- \\
\hline$P$ & $1.29 E+03$ & $<3.12 E+02$ & $<4.27 E+02$ & $<2.58 E+02$ & $<1.08 E+02$ & -- \\
\hline $\mathrm{Pb}$ & $<1.75 E+02$ & $<1.59 E+02$ & $<2.17 E+02$ & $<1.31 E+02$ & $<5.45 E+01$ & -- \\
\hline$S$ & $1.37 \mathrm{E}+03$ & $8.10 \mathrm{E}+03$ & $2.25 \mathrm{E}+03$ & $1.91 \mathrm{E}+03$ & $3.80 E+03$ & $7.13 E+01$ \\
\hline $\mathrm{Sb}$ & $<1.07 E+02$ & $<9.71 E+01$ & $<1.33 E+02$ & $<8.05 E+01$ & $3.66 \mathrm{E}+01$ & $1.58 E+00$ \\
\hline $\mathrm{Se}$ & -- & -- & -- & -- & $<1.11 \mathrm{E}+00$ & -- \\
\hline $\mathrm{Si}$ & $<2.63 E+01$ & $<2.38 E+01$ & $<3.25 E+01$ & $<1.97 E+01$ & $<8.21 E+00$ & -- \\
\hline Sn & $<1.75 E+02$ & $<1.57 E+02$ & $<2.16 E+02$ & $<1.31 E+02$ & $<5.43 E+01$ & -- \\
\hline $\mathrm{Sr}$ & $<7.10 E+01$ & $<6.44 E+01$ & $<8.79 E+01$ & $<5.34 E+01$ & $<2.22 E+01$ & -- \\
\hline $\mathrm{Ti}$ & $<4.26 E+00$ & $<3.86 E+00$ & $<5.28 E+00$ & $<3.20 E+00$ & $<1.33 E+00$ & -- \\
\hline $\mathrm{V}$ & $<7.81 E+00$ & $<7.07 E+00$ & $<9.68 E+00$ & $<5.86 E+00$ & $<2.44 E+00$ & -- \\
\hline $\mathrm{Zn}$ & $7.57 E+01$ & $<3.54 E+01$ & $<4.83 E+01$ & $<2.94 E+01$ & $<1.22 E+01$ & -- \\
\hline $\mathrm{Zr}$ & $<8.51 E+00$ & $<7.71 E+00$ & $<1.06 E+01$ & $<6.40 E+00$ & $<2.67 E+00$ & -- \\
\hline
\end{tabular}


WSRC-TR-2004-00130

Revision 0

Table 9: ICP-MS Analysis of the Dissolution of Drained Tank 29H Saltcake (Bulk Filtered)

\begin{tabular}{|l|c|c|}
\hline \multicolumn{3}{|c|}{ T29H-B6-1 Bulk Dissolution } \\
\hline \multicolumn{1}{|c|}{$(\mathrm{mg} / \mathrm{L})$} & \multicolumn{1}{c|}{ Average } & \multicolumn{1}{c|}{ StDev } \\
\hline Mass 59 $(\mathrm{Co})$ & $<1.85 \mathrm{E}-01$ & -- \\
\hline Mass $88(\mathrm{Sr})$ & $<2.49 \mathrm{E}-02$ & -- \\
\hline Mass $99(\mathrm{Tc}, \mathrm{Ru})$ & $1.39 \mathrm{E}+00$ & $7 \mathrm{E}-02$ \\
\hline Mass 101 $(\mathrm{Ru})$ & $6.10 \mathrm{E}-02$ & $3.5 \mathrm{E}-03$ \\
\hline Mass 133 $(\mathrm{Cs})$ & $1.66 \mathrm{E}+00$ & $2 \mathrm{E}-02$ \\
\hline Mass 135 $(\mathrm{Cs}, \mathrm{Ba})$ & $2.88 \mathrm{E}-01$ & $1.3 \mathrm{E}-02$ \\
\hline Mass 137 $(\mathrm{Cs}, \mathrm{Ba})$ & $9.16 \mathrm{E}-01$ & $1.7 \mathrm{E}-02$ \\
\hline Mass 138 $(\mathrm{Ba})$ & $<3.55 \mathrm{E}-02$ & -- \\
\hline Mass 230 - 234 & $<2.28 \mathrm{E}-02$ & -- \\
\hline Mass 235 $(\mathrm{U})$ & $4.69 \mathrm{E}-02$ & $1.08 \mathrm{E}-02$ \\
\hline Mass 236 $(\mathrm{U})$ & $2.36 \mathrm{E}-02$ & $8 \mathrm{E}-04$ \\
\hline Mass 237 $(\mathrm{Np})$ & $<2.28 \mathrm{E}-02$ & -- \\
\hline Mass 238 $(\mathrm{U}, \mathrm{Pu})$ & $3.95 \mathrm{E}-01$ & $9.2 \mathrm{E}-02$ \\
\hline Mass 239 -245 & $<2.28 \mathrm{E}-02$ & -- \\
\hline Total U $(\mathrm{mg} / \mathrm{L})$ & $4.66 \mathrm{E}-01$ & $1.0 \mathrm{E}-01$ \\
\hline $235 \mathrm{U}$ enrichment $(\%)$ & $10.1 \%$ & $0.1 \%$ \\
\hline
\end{tabular}

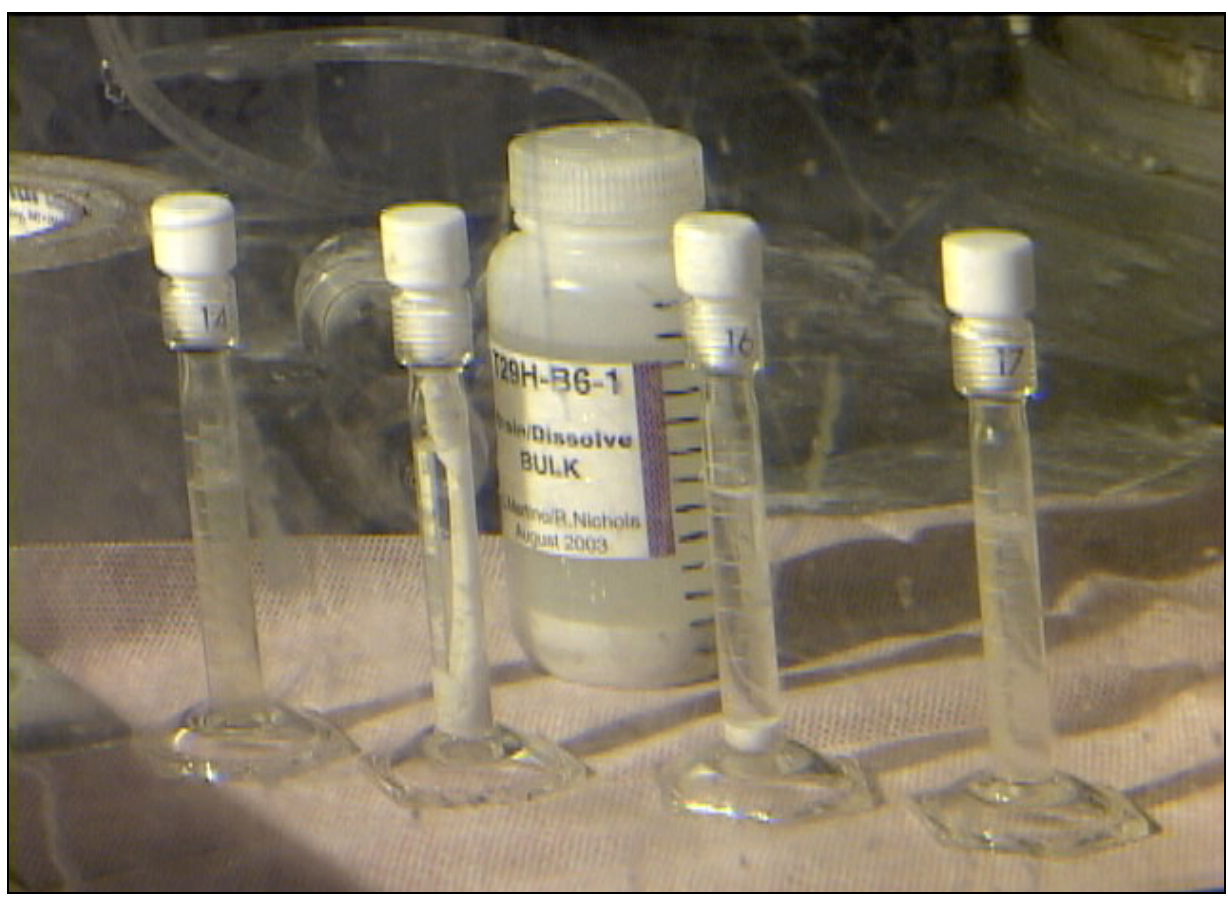

Figure 8: Tank 29H Dissolved Samples 


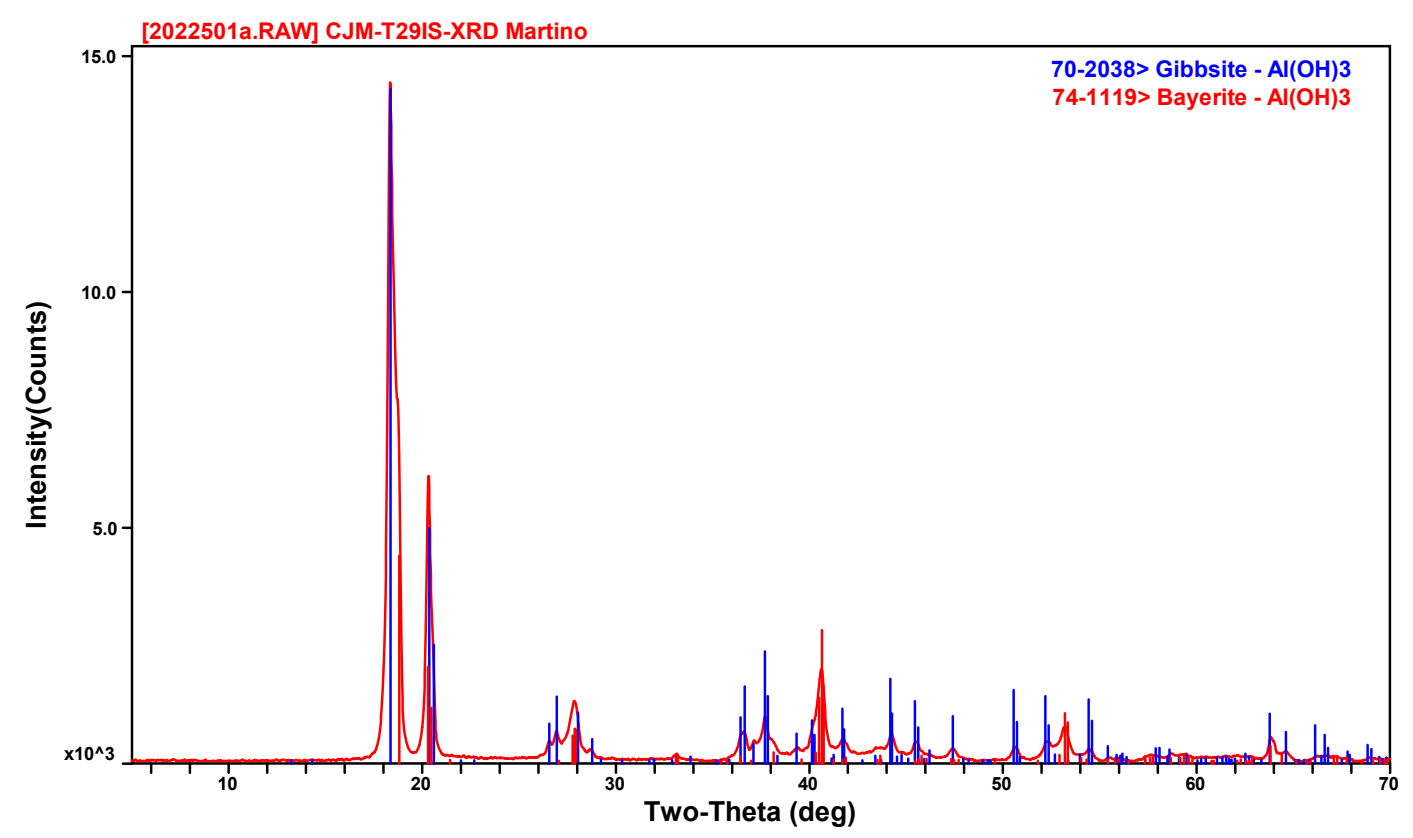

Figure 9: XRD analysis of insoluble solids resulting from dissolution of Tank $29 \mathrm{H}$ saltcake

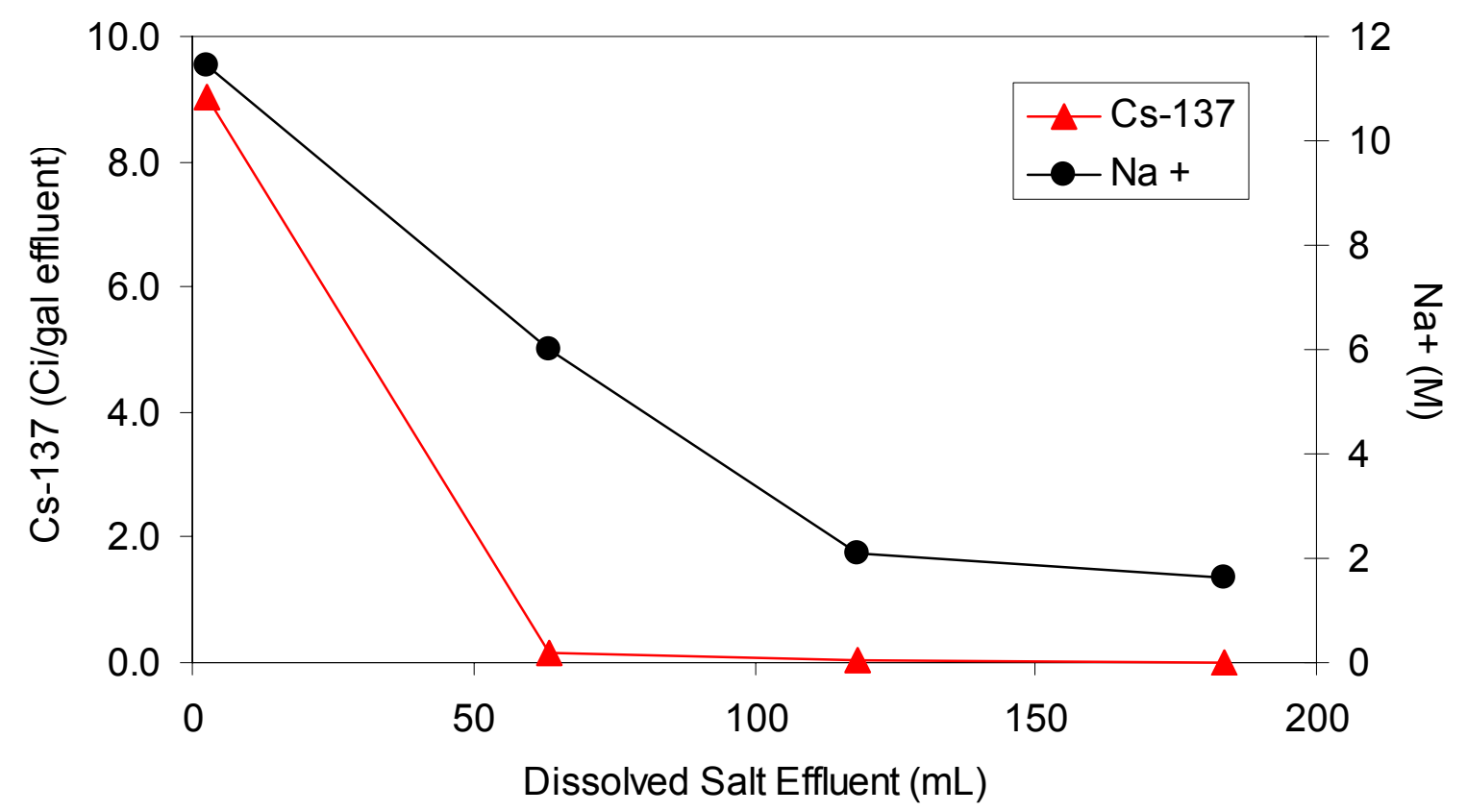

Figure 10: Tank 29H flow-through dissolution profiles for ${ }^{137} \mathrm{Cs}$ and $\mathrm{Na}^{+}$ 
WSRC-TR-2004-00130

Revision 0

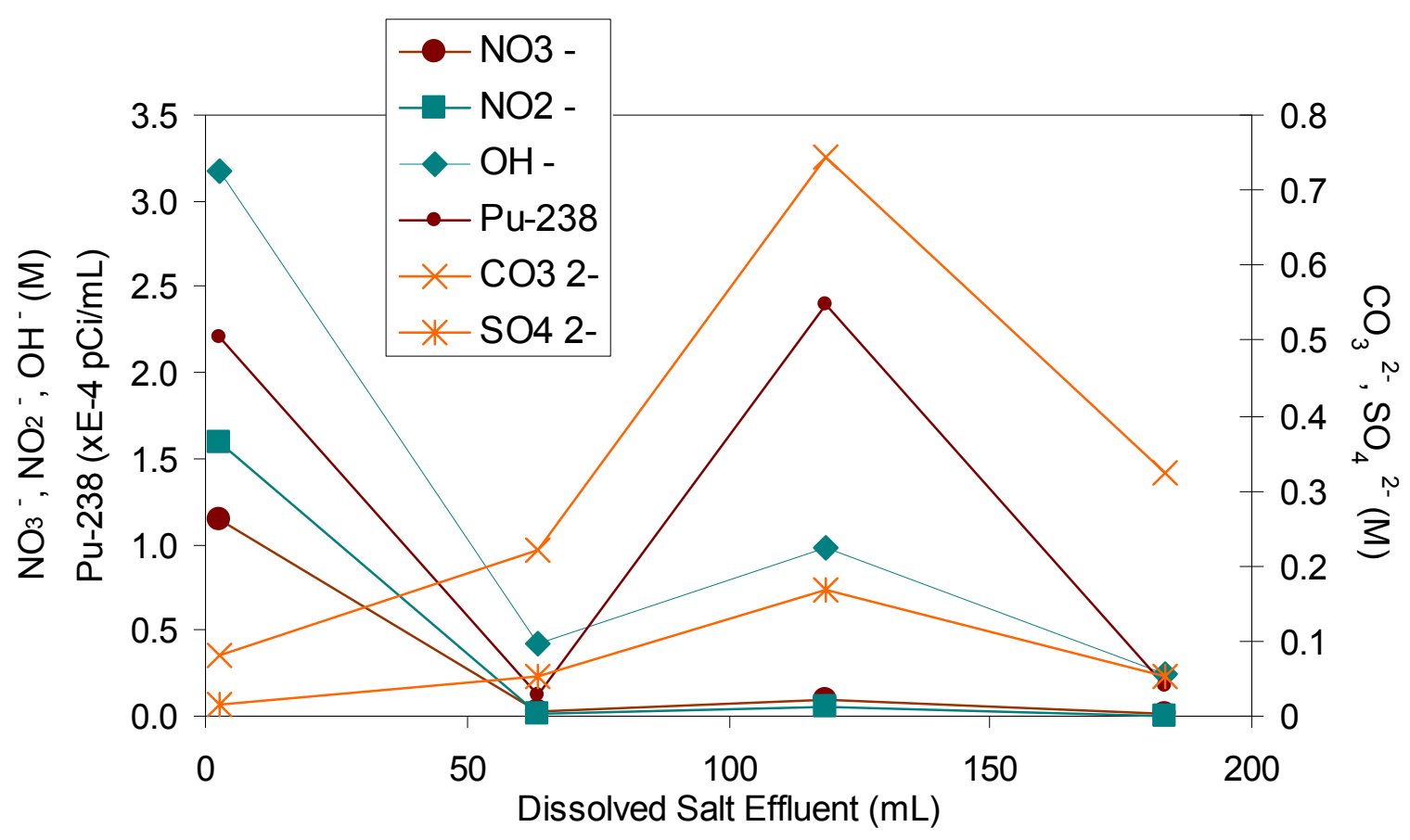

Figure 11: Tank 29H flow-through dissolution profiles for anions and Pu-238

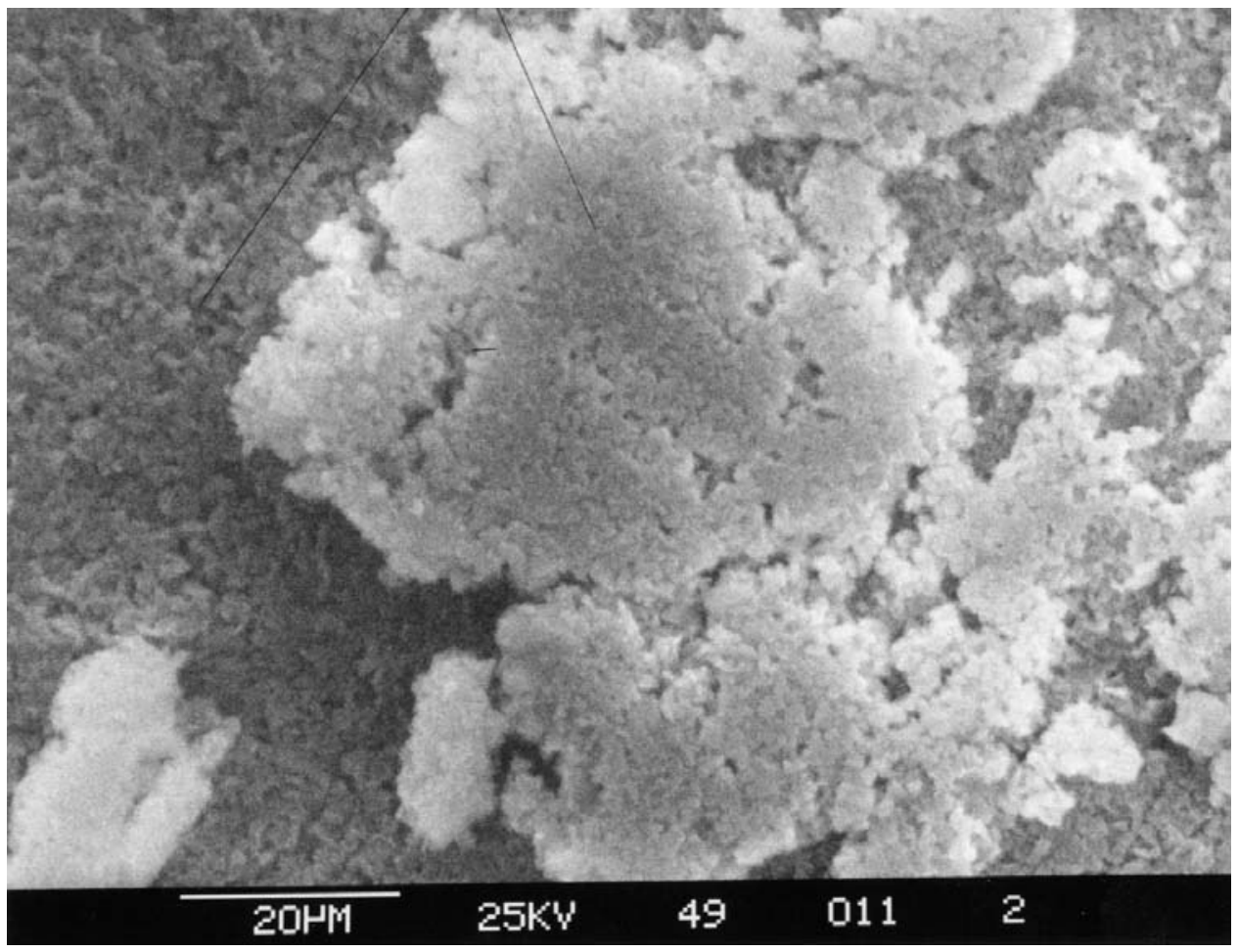

Figure 12: SEM photograph of solids remaining from dissolution tests 


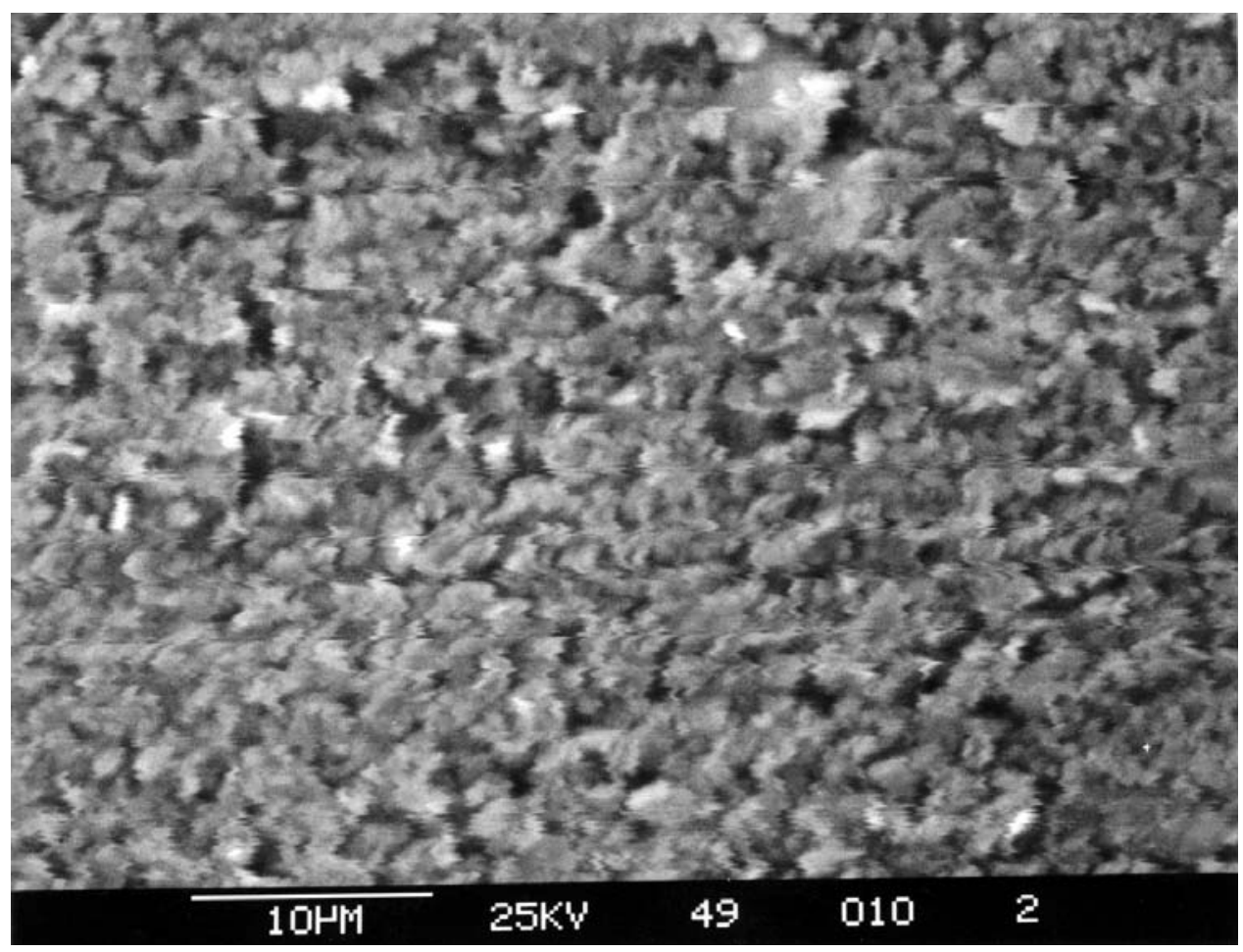

Figure 13: SEM photograph of second area of solids remaining from dissolution tests

TN-5502 WSRC CSEM.

TUE 18-NOV-03 15:48

Cursor: $0.000 \mathrm{keV}=0$

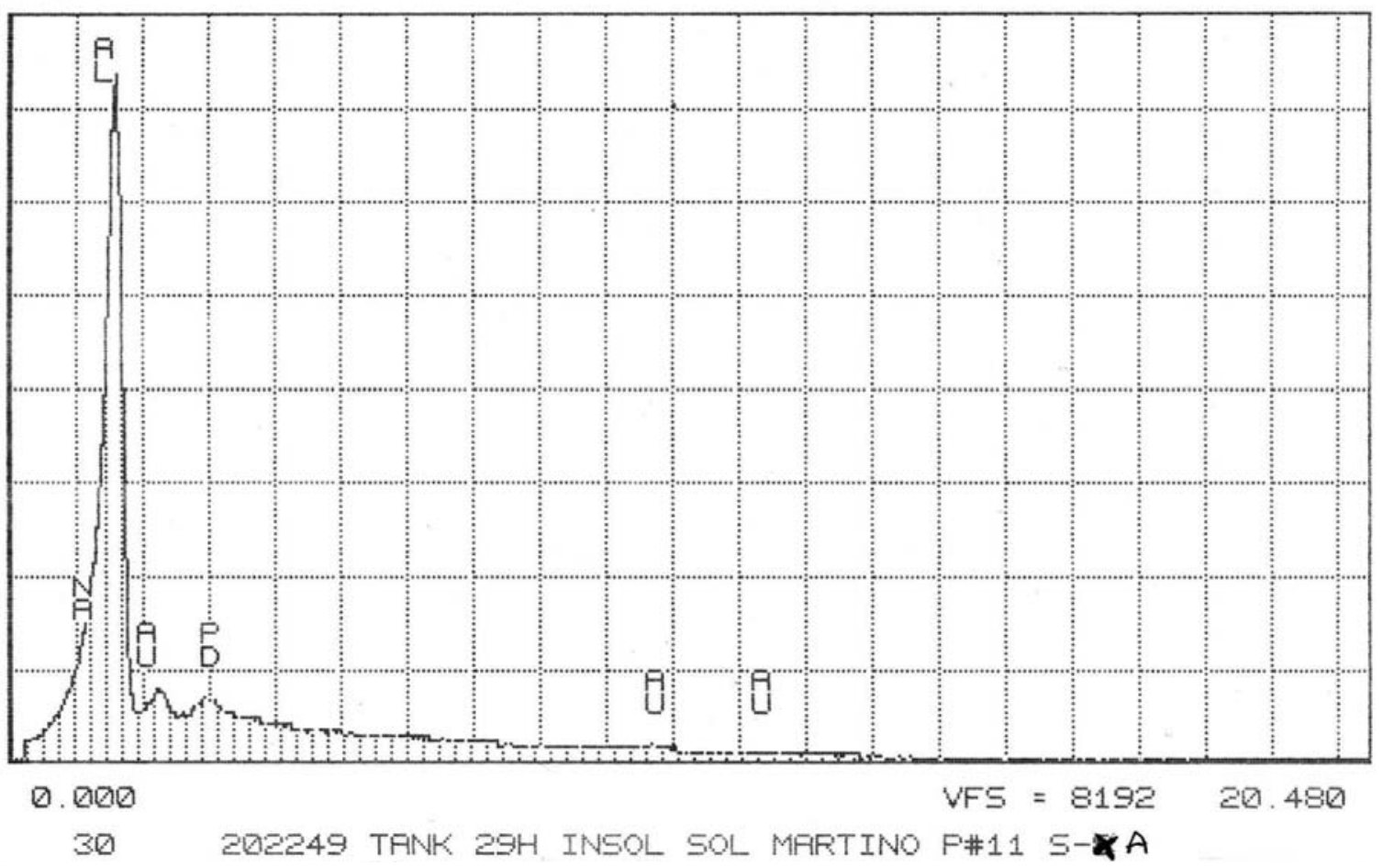

Figure 14: X-ray EDS of solids remaining from dissolution tests 
WSRC-TR-2004-00130

Revision 0

\section{Physical Analyses}

The bulk density of the saltcake sample from tank $29 \mathrm{H}$ was greater than the bulk density reported for saltcake samples collected previously from Tanks $2 \mathrm{~F}, 3 \mathrm{~F}$, and $41 \mathrm{H}$, as shown in Table 10 . The increased bulk density is most likely due to a higher aluminum content (13 wt\%) in the tank $29 \mathrm{H}$ sample when compared to the saltcake in the Tanks $2 \mathrm{~F}, 3 \mathrm{~F}$, and $41 \mathrm{H}(0.1-1 \mathrm{wt} \%)$ samples. Porosity and saturation were not estimated for the sample due to a lack of information on the crystal phases of aluminum species in the sample. However, if it is assumed that the sample was saturated, the estimated porosity would be $56 \%$ and the density of salt particles would be $2.96 \mathrm{gm} / \mathrm{cc}$.

Saturation of the tank $29 \mathrm{H}$ sample with Simulated Interstitial Liquid (SIL) was initiated on November 19, 2003 to prepare the sample for a falling head test to determine the permeability of the sample. Approximately $1 \mathrm{~mL}$ of SIL entered the sample after 7 days. The falling head test was subsequently terminated due to the slow saturation process. Several adjustments were made to the falling head apparatus to ensure that the test equipment was not preventing SIL from entering the sample during the saturation step of the procedure. These results suggest that either the sample had a very low permeability or that the SIL was unable to displace the residual IL that was in the sample. Additionally, the sample had likely cooled from the tank temperature of $47^{\circ} \mathrm{C}$ to the laboratory temperature of $\sim 25^{\circ} \mathrm{C}$ reducing the solubility of some salts in the residual IL and resulting precipitation of salts in existing pores, which ultimately reduced the permeability of the sample.

Interstitial liquid extraction of sample T29H-B6-1-A removed 13.3 grams of IL from $112 \mathrm{gm}$ of saltcake, Figure 13. Based on as-received sampling results this means $28 \%$ (vol/vol) of the IL in the sample was removed during IL extraction using 10" Hg vacuum, Figure 14 (17\% of the total sample volume).

Table 10. Physical properties of saltcake samples.

\begin{tabular}{|c|c|c|c|c|c|}
\hline Sample ID & $\begin{array}{c}\text { Sample } \\
\text { Interval } \\
\text { (ft) }\end{array}$ & $\begin{array}{c}\text { Bulk } \\
\text { Density } \\
\left(\mathrm{g} / \mathrm{cm}^{3}\right)\end{array}$ & $\begin{array}{c}\text { Water } \\
\text { Content } \\
\theta_{\text {water }} \\
(\text { Wt \%) } \\
\end{array}$ & $\begin{array}{l}\text { Porosity } \\
\phi(\text { vol \%) }\end{array}$ & $\begin{array}{l}\text { Saturation } \\
\text { S (vol \%) }\end{array}$ \\
\hline T29H-B6-1 & $0-1$ & 2.13 & 21 & nd & nd \\
\hline T2F-1-1 & $0-1$ & 2.04 & $6.2 \pm 0.6$ & 23 & 77 \\
\hline $\begin{array}{l}\text { T3F-1-3 } \\
\text { (Tank 3) }\end{array}$ & $1-2$ & 2.07 & $5.1 \pm 2.6$ & 19 & 76 \\
\hline $\mathrm{T} 41 \mathrm{H}$ & $1-2$ & $1.92^{\mathrm{a}}$ & $3.2^{\mathrm{a}}$ & 22 & 34 \\
\hline
\end{tabular}




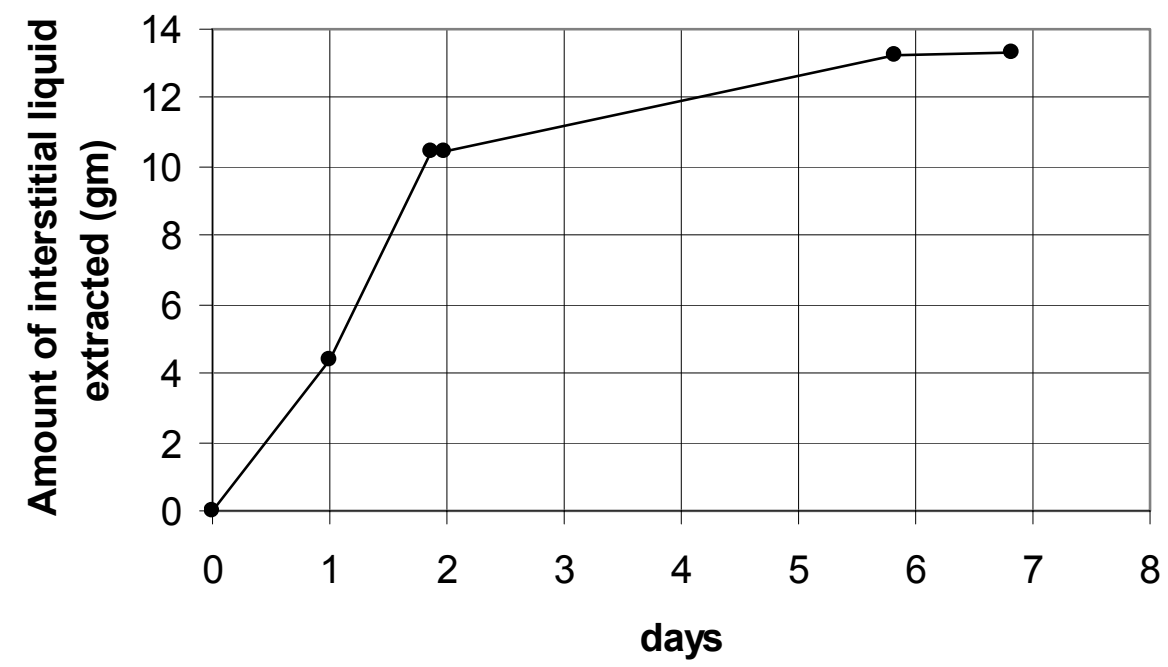

Figure 15: Extraction of interstitial liquid from T29H B6-1-A

10" Hg Vacuum, 6.7 days

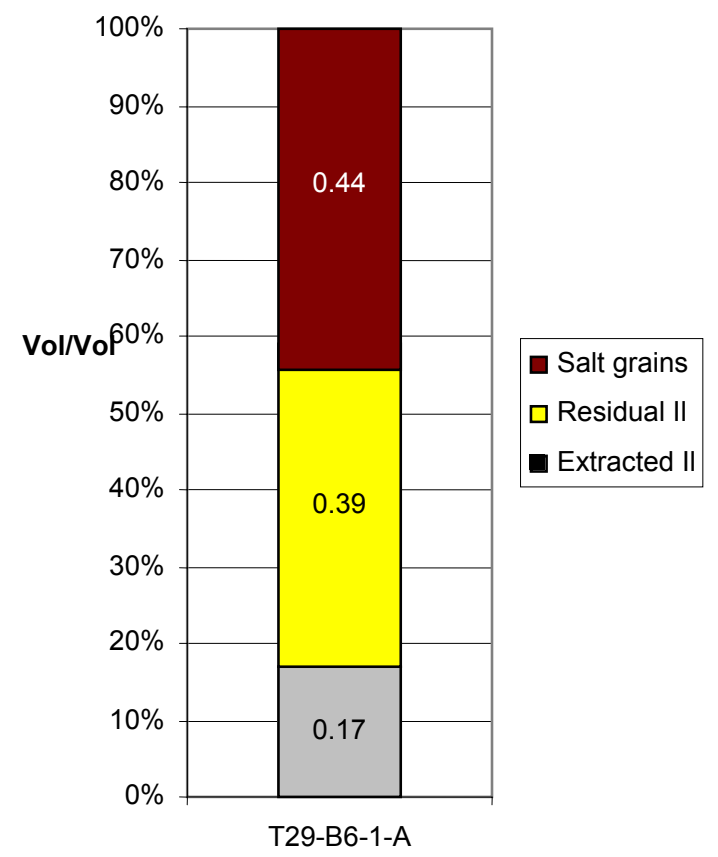

Figure 16: Volume percent of residual and extracted interstitial liquid in T29H-B6-1-A following vacuum extraction 
WSRC-TR-2004-00130

Revision 0

\section{Discussion}

As evidenced by data shown in Tables $3-5$, the supernate dip sample from Tank $29 \mathrm{H}$ is substantially different from the saltcake and interstitial liquid. This is not surprising since the last liquids added to the tank were low ionic strength solutions (condensate and rainwater) onto the top of the saltcake. The density of the dip sample is lower than the interstitial liquid, but it does not just appear to be a difference in saturation level. The ratios of nitrate, nitrite, hydroxide, and aluminate are different for the two liquids, with high nitrate in the dip sample, and high nitrite in the interstitial liquid.

Filtering the as-received dip sample removed approximately $72 \%$ of the Pu with a 0.45 -micron filter. Filtering with a 0.1 micron filter did not further reduce the Pu content, within experimental accuracy. Conversely, less than half of the $U$ is removed by filtration (21-37\%). These data suggest that most of the $\mathrm{Pu}$ and some of the $\mathrm{U}$ is in suspension in the supernate, consistent with the observed (brown) turbidity of the solution (Figure 4). The results for Sr-90 are not explainable. An error in sample handling is suspected.

In the bulk, undrained saltcake and interstitial liquid, almost all (>90\%) of the actinides are partitioned to the saltcake phase. Dissolution of this phase, and the partitioning of radionuclides are discussed later in the text.

As expected, the radionuclides C-137 and Tc-99 are entirely soluble in the interstitial liquid within experimental error. This is shown in the last column of Table 3, where the percent of each component that is distributed in the liquid is shown. To indirectly confirm the volume $\%$ of the liquid phase in the saltcake sample, the Cs-137 concentration and densities can be used. This indicates that the liquid phase is $54 \mathrm{vol} \%$ of the bulk saltcake, in good agreement with the $56 \mathrm{vol} \%$ calculated from the quantity of water determined by drying, and the mass of cations and anions in the liquid. The calculations for DIL that exceed $100 \%$ (e.g. phosphate) are not tenable and indicate experimental and analytical variability in these minor species.

The percent volume of liquid in this sample is at the high end of the range of typical saturated saltcakes. This may be related to the high aluminum content of this sample, versus most saltcakes which are overwhelmingly sodium nitrate crystals. The difference may have profound impacts on the draining characteristics of this waste tank, although it is unlikely that this sample represents the average contents of this tank. If this composition is similar throughout the tank, more interstitial liquid may generated upon draining, and more may be retained by the remaining saltcake. Tank-wide modeling studies indicate that the best estimate for saltcake contains around $40 \%$ total void space, with $30 \%$ liquid and $10 \%$ gas. ${ }^{4} \mathrm{~A}$ tank with higher liquid volume would be expected to have different percolation and draining characteristics, although the magnitude of the impact is not known.

Table 4 shows the principal component distribution of the saltcake, interstitial liquid, and supernate dip samples. Table 5 shows the minor elemental compositions, and Table 6 identifies the likely major components of a theoretically completely dry saltcake, shown schematically in Figure 17 . The saltcake composition is calculated by excluding the liquid phase components, in proportion to the mass of each and the phase ratio. Compositions of salts, and the number of waters of hydration, are assumed and have not been independently analyzed. As can be seen, the sample is almost entirely sodium aluminate.

Analysis of the bulk saltcake for total base analysis indicated the presence of $14.9 \mathrm{wt} \%$ (calculated as hydroxide ion), and $7.71 \mathrm{wt} \%$ free hydroxide. The interstitial liquid analysis indicates $5.32 \mathrm{wt} \%$ free hydroxide, suggesting insoluble sodium hydroxide. The presence of insoluble sodium hydroxide is unlikely in tank waste, and an alternate explanation is needed. A possible explanation for the observation is that some of the insoluble sodium aluminate disproportionated to sodium hydroxide and aluminum hydroxide during the sample preparation in water. Preparation of the sample for analysis of the bulk undrained saltcake was done by dissolving the sample in water and analyzing for anions. Using the independent analyses of aluminum and carbonate in the bulk waste, more than $95 \%$ of the total base in the bulk waste can be accounted for as sodium aluminate. This indicates that the free hydroxide 
measurement in bulk saltcake is correct, but the apparent insolubility is an anomaly of the chemistry of the sample preparation with this high aluminum matrix. This likely has implications for the dissolution of this tank, as additional sodium hydroxide would be needed to dissolve the aluminum hydroxide (discussed further below).

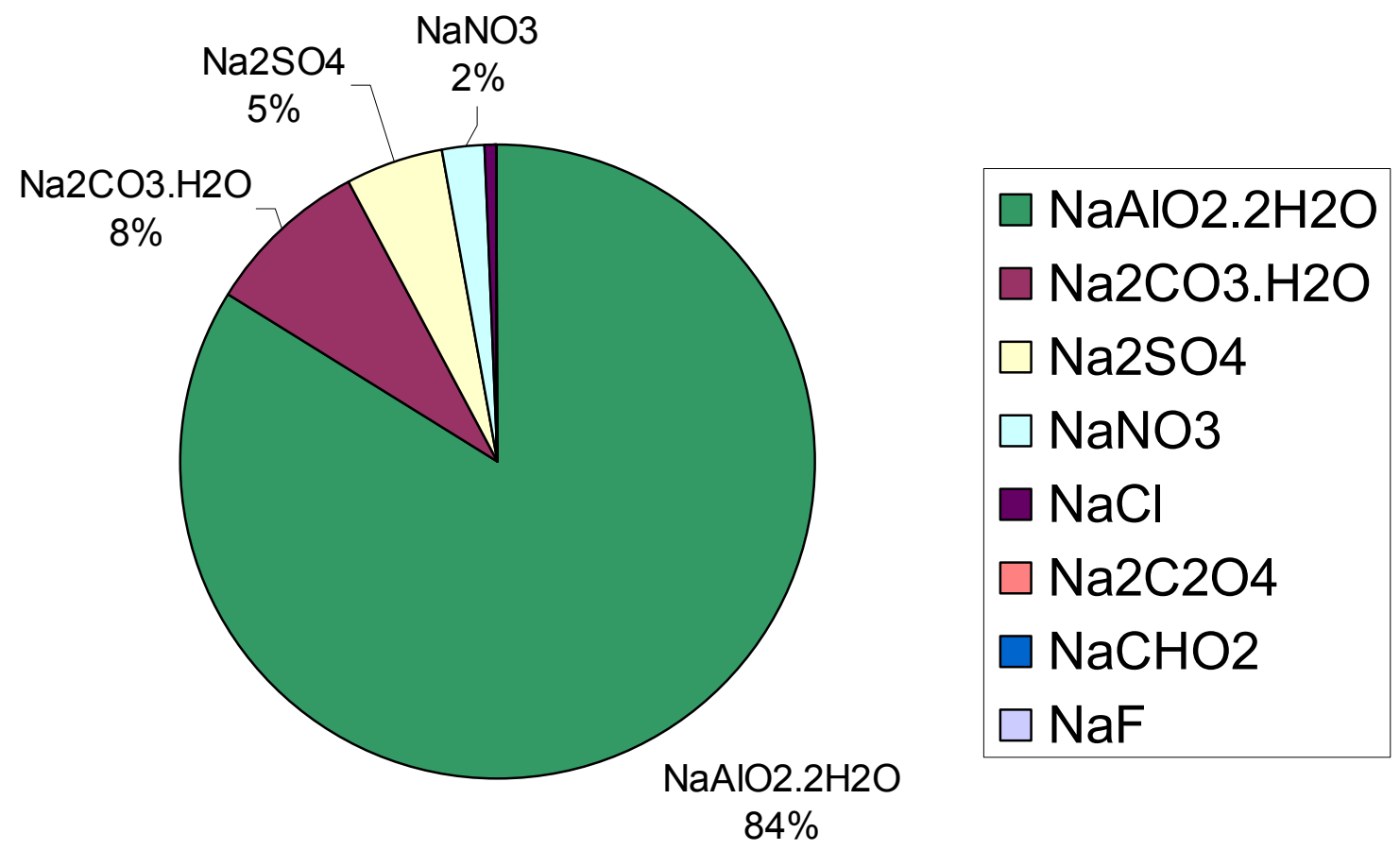

Figure 17: Likely major components of Tank $29 \mathrm{H}$ saltcake solids, normalized

The saltcake sample was partially drained of interstitial liquid prior to dissolution testing. Out of a total of $112.2 \mathrm{~g}(52.7 \mathrm{~mL})$ of undrained saltcake, draining under 10 inches $\mathrm{Hg}$ vacuum for 6.8 days, removed 13.3 $\mathrm{g}(8.99 \mathrm{~mL})$ of interstitial liquid. This left approximately $98.9 \mathrm{~g}$ of saltcake and residual interstitial liquid at the start of the dissolution test. The liquid that was removed during vacuum draining was only 17 vol\%, versus a calculated 56 vol\% liquid present (based on total sample volume). While the amount drained is consistent with tank $41 \mathrm{H}$ draining behavior, the residual liquid volume $(39 \mathrm{vol} \%)$ is not. This calculation can be compared with the sum of cesium from the dissolution aliquots. The total Cs-137 in the residual 39 vol\% interstitial should be $5.14 \mathrm{E}+10 \mathrm{pCi}$. Summing the $\mathrm{Cs}-137$ in the filtered bulk sample and four subsamples is $3.31 \mathrm{E}+10 \mathrm{pCi}$, a $64 \%$ recovery. It is possible that the discrepancy is due to differences in the saturation of the dissolution sample versus the analyzed sample, which were from different sections of the tube. However, these results, if representative of the full tank composition, indicate that this saltcake will retain more liquid, and hence more Cs-137 and Tc-99, than other tanks. This behavior is likely related to the unique composition of this waste, which is very low in sodium nitrate and very high in aluminate species. This is could be because the low ionic strength liquids added to the top of the saltcake over the past few years, coupled with fact that this sample was from the bottom of a mined well, dissolved the top layer of sodium nitrate and left sodium aluminate behind by some mechanism. Even if this sample is not representative of the tank contents, it indicates that a wide range of compositions and physical properties that can be present, and current models need to be adjusted to accommodate the variable nature of the tanks. If it is assumed that this is a layer of aluminum above a typical salt tank, this observation also exemplifies the formation of a phase with relatively low solubility and possibly low permeability on top of a highly soluble phase. Settling of an aluminum-rich phase in the bottom of the mined well may also have contributed to the non-representative nature of this sample. 
From the estimated composition of the saltcake, the white solids likely formed during the dissolution demonstration from disproportionation of sodium aluminate to aluminum hydroxide and sodium hydroxide. The fine particulate aluminum hydroxide likely built up at the top of the saltcake during dissolution, prohibiting the water from contacting additional salt. This phenomenon was noted by Mississippi State University DIAL during similar dissolution testing of Hanford high-aluminum saltcake simulant. ${ }^{6}$ In a tank, this phenomenon may manifest as slow dissolution and percolation rates, depending on the water addition method, impacting tank waste retrieval schedules. Even if this is not representative of the tank, the presence of layers of high aluminate phases would likely cause formation of low permeability layers during subsequent dissolutions. Further study is recommended to examine the quantity and conditions for sodium hydroxide additions needed to avoid precipitation of aluminum hydroxide during tank waste retrieval, and to examine the water addition methods that mitigate slow percolation rates.

Although the second dissolution aliquot has a relatively low sodium molarity, compared to typical salt solutions, it may be saturated with respect to equilibrium with the "atypical saltcake" which is present after the first dissolution step. Since the anion-cation balance is poor, it is not possible to determine if the solution is saturated. Further laboratory testing and computer modeling are needed to determine the degree of saturation of this solution.

The Pu-238 solubility behavior during dissolution is interesting. Between the first and second dissolution, the Pu decreases, trending with hydroxide ion, but increases in the third sample, trending with carbonate ion. This suggests that two Pu species are present or form during dissolution. This observation does not exclude a possible role for other anions also, such as oxalate, that are near the detection limits. It is not proven here that this dissolution solution was saturated to its solubility limit with $\mathrm{Pu}$ or $\mathrm{U}$, and further testing would be needed to determine if more of these radionuclides dissolve on prolonged contact of the salt solution with saltcake solids at tank temperatures. Although the Pu was largely removed by filtration, this may not represent the behavior in a tank environment due to the slow kinetics of Pu dissolution in salt solution. Settling may not remove the Pu to the same degree as filtration, as the species may be present as colloids. In this experiment, the dissolution test subsamples were settled, and the liquid withdrawn from above the settled solids with a pipette, indicating that the Pu remains in suspension to some extent. The short contact times and low temperatures used in the experiments will not mimic the conditions in a waste tank. Furthermore, if sodium hydroxide is added to facilitate aluminum dissolution, both the hydroxide content and aluminum content will impact the Pu solubility. ${ }^{7}$

Solubility of the saltcake for this tank sample is relatively low. The total yield of dissolved salt is estimated at $66 \%$ of the mass of original saltcake. The sum of aluminum that dissolved in all the dissolution steps was only $27 \%$ of the total calculated present in the bulk sample. The volume of aluminum hydroxide solids remaining after dissolution $(\sim 40 \mathrm{~mL})$ approaches the volume of the original saltcake sample (52.7 $\mathrm{mL}$ ). Addition of sodium hydroxide to dissolve the aluminum species would likely increase the yield of retrievable waste. The kinetics of redissolution can also be slow at ambient temperature, depending on the degree of crystallinity, temperature, and particle size.

\section{Conclusions}

The supernate dip sample from Tank $29 \mathrm{H}$ is substantially different from the saltcake and interstitial liquid. This is thought to be because low ionic strength liquids were added to the top of the saltcake during the past few years, and some of the dissolved salt was removed. Approximately $72 \%$ of the $\mathrm{Pu}$ and $\sim 25 \%$ of the $U$ is in suspension in the supernate and can be removed by filtration.

As expected, the radionuclides C-137 and Tc-99 are entirely soluble and the actinides are largely (>90\%) insoluble, in the interstitial liquid, within experimental error.

It is not known how well this sample represents the average contents of the entire tank. Addition of low ionic strength liquid to the top of the saltcake/supernate and well mining operations probably dissolved some species and left behind others. There is considerably more aluminum and liquid present in this sample than in most other tank samples examined thus far. If this high aluminum composition is similar 
throughout the tank, more interstitial liquid may be released upon draining, and more will be retained by the remaining saltcake than current computer models predict. The draining and percolation characteristics are also expected to be different, although the magnitude of the impact is not known. If this aluminum phase forms a low permeability layer on top of the saltcake, this may impact the waste dissolution rate, and thus the retrieval schedule. Different water addition methods would likely be impacted in different ways by the presence of a low permeability layer. The high aluminum content of this sample has implications for the dissolution chemistry also, as additional sodium hydroxide would be needed to dissolve the aluminum hydroxide. The high concentration of what appears to be sodium aluminate led to precipitation of aluminum hydroxide during the draining/dissolution test, and only about $66 \%$ of the original salt (by mass) partitioned to the aqueous phase during the drain/dissolution demonstration. The sum of aluminum that dissolved in all the dissolution steps was only $27 \%$ of the total calculated present in the bulk sample. The volume of aluminum hydroxide solids remaining after dissolution was $76 \%$ of the original saltcake sample volume. Although the Pu was largely removed from the dissolved salt by filtration, this may not represent the behavior in a tank environment due to the slow kinetics of Pu dissolution in salt solution.

Additional characterization of this tank is recommended to determine if this sample is representative of the tank contents. Further study is also recommended to examine the quantity and conditions for sodium hydroxide additions needed to avoid precipitation of aluminum hydroxide, and to examine the kinetics of $\mathrm{Pu}$ and $\mathrm{U}$ dissolution.

\section{Quality Assurance}

This work satisfies the requirements of the original task technical and quality assurance plan. ${ }^{8}$ Laboratory Notebooks WSRC-NB-2003-00072, WSRC-NB-2003-00177, WSRC-NB-2003-00199, and various ADS notebooks contain the experimental data.

\section{Acknowledgements}

The authors thank the following for their important contributions to this project. John Sessions, Glen Johnson, and Dennis Conrad of the Closure Business Unit; Nancy Gregory and Sharon Smith in SRTC Waste Processing Technology; Monica Jenkins, Mona Galloway, Monica Miller, Rita Sullivan, Carolyn Conley, Ron Blessing and many others in SRTC Shielded Cells Operations; Tom Nance and Dan Krementz of SRTC Remote Specialty Equipment; Curt Sexton of the SRTC Glass-blowing Shop; Leigh Brown, Dave Diprete, Ceci Diprete, Theresa Eddy, June Hart, Damon Click, Bill Boyce, Mira Malek, Chuck Coleman, Beverly Burch, John Young, Amy Ekechukwu, Robert Ray, Michael Whitaker, Art Jurgensen, Dave Missimer, Wilson Smith, and many technicians of SRTC Analytical Development.

\section{References}

1 J. R. Sessions, "Saltcake Characterization to Support Closure Activities," CBU-SPT-2003-00126, Rev. 0, July 17, 2003.

${ }^{2}$ D. T. Conrad, "LCS Sampling and Analysis Plan for Process Validation," CBU-SPT-2003-00164, Rev. 0, September 9, 2003.

${ }^{3}$ R.L. Nichols and C.J. Martino, Hydraulic Properties of Saltcake Samples from Tank41H (U), WSRC-TR2003-00543, January, 2004

${ }^{4}$ G. P. Flach, "Porous Medium Analysis of Interstitial Fluid Removal from Tank 41 and Tank $3(\mathrm{U})$ ", WSRC-TR-2003-0533, Rev. 0. 
WSRC-TR-2004-00130

Revision 0

${ }^{5}$ M. D. Drumm, "Feed Basis for Processing Relatively Low Radioactivity Waste Tanks," WSRC-TR-200100559, Rev. 2, November 21, 2002.

${ }^{6}$ J. Lindner et al., "Salt Waste Alternative Processing and Chemistry Support - I," in "SRS-Hanford Salt Retrieval Technical Exchange April 22-23, 2003," W. R. Wilmarth and K. Gasper, eds., WSRC-MM-200300067, May 2003.

${ }^{7}$ D.T. Hobbs, T.B. Edwards, "Solubility of Plutonium in Alkaline Salt Solutions (U)", WSRC-TR-93-131, February 26, 1993.

${ }^{8}$ R. L. Nichols and C. J. Martino, "Task Technical and Quality Assurance Plan for the Characterization of Drained Low-Curie Saltcake," WSRC-RP-2003-00319, Rev. 1, June 3, 2003. 


\section{Appendix}

Table 10: Undrained Bulk Saltcake rad. chem. results (pCi/g)

\begin{tabular}{|c|cc|}
\hline Sample: & \multicolumn{2}{|c|}{ T29H-B6-1 } \\
\hline$(\mathrm{pCi} / \mathrm{g})$ & Average & St. Dev. \\
\hline${ }^{14} \mathrm{C}$ & $9.9 \mathrm{E}+02$ & -- \\
\hline${ }^{90} \mathrm{Sr}$ & $1.35 \mathrm{E}+07$ & $4.9 \mathrm{E}+06$ \\
\hline${ }^{137} \mathrm{Cs}$ & $6.40 \mathrm{E}+08$ & $2.0 \mathrm{E}+07$ \\
\hline${ }^{238} \mathrm{Pu}$ & $1.12 \mathrm{E}+06$ & $1.0 \mathrm{E}+05$ \\
\hline${ }^{239 / 240} \mathrm{Pu}$ & $1.79 \mathrm{E}+04$ & $1.5 \mathrm{E}+03$ \\
\hline${ }^{241} \mathrm{Am}$ & $1.13 \mathrm{E}+04$ & $2.2 \mathrm{E}+03$ \\
\hline
\end{tabular}

Table 11: Undrained Bulk Saltcake IC Anions, wet chemistry titration, and TIC/TOC results (g/100g)

\begin{tabular}{|c|rc|}
\hline Sample: & \multicolumn{2}{|c|}{ T29H-B6-1 } \\
\hline$(\mathrm{g} / 100 \mathrm{~g})$ & Average & St. Dev. \\
\hline $\mathrm{NO}_{3}{ }^{-}$ & \multicolumn{3}{|c|}{$5.38 \mathrm{E}+00$} & $7.7 \mathrm{E}-01$ \\
\hline $\mathrm{NO}_{2}{ }^{-}$ & $3.03 \mathrm{E}+00$ & $1.5 \mathrm{E}-01$ \\
\hline $\mathrm{SO}_{4}{ }^{2-}$ & $2.19 \mathrm{E}+00$ & $4 \mathrm{E}-02$ \\
\hline $\mathrm{PO}_{4}{ }^{3-}$ & $7.91 \mathrm{E}-02$ & $9.0 \mathrm{E}-03$ \\
\hline $\mathrm{Cl}^{-}$ & $2.02 \mathrm{E}-01$ & $2.68 \mathrm{E}-01$ \\
\hline $\mathrm{F}^{-}$ & $<9.68 \mathrm{E}-03$ & -- \\
\hline $\mathrm{C}_{2} \mathrm{O}_{4}{ }^{2-}$ & $<4.84 \mathrm{E}-02$ & -- \\
\hline $\mathrm{CHO}_{2}{ }^{-}$ & $<4.84 \mathrm{E}-02$ & -- \\
\hline $\mathrm{Free} \mathrm{OH}^{-}$ & $7.71 \mathrm{E}+00$ & $1.67 \mathrm{E}+00$ \\
\hline $\mathrm{CO}_{3}{ }^{2-}($ titration$)$ & $<5.81 \mathrm{E}+00$ & -- \\
\hline $\mathrm{CO}_{3}{ }^{2-}(\mathrm{TIC})$ & $3.02 \mathrm{E}+00$ & $2.1 \mathrm{E}-01$ \\
\hline $\mathrm{TOC}^{2}$ & $3.9 \mathrm{E}-01$ & $1.4 \mathrm{E}-01$ \\
\hline
\end{tabular}


WSRC-TR-2004-00130

Revision 0

Table 12: Undrained Bulk Saltcake ICP-ES results (g/100g)

\begin{tabular}{|c|c|c|}
\hline Sample: & \multicolumn{2}{|c|}{ T29H-B6-1 } \\
\hline$(g / 100 g)$ & Average & St. Dev. \\
\hline $\mathrm{Ag}$ & $<6.94 E-04$ & -- \\
\hline $\mathrm{Al}$ & $1.33 E+01$ & $2 \mathrm{E}-01$ \\
\hline B & $<7.50 E-02$ & -- \\
\hline $\mathrm{Ba}$ & $<6.94 E-04$ & -- \\
\hline $\mathrm{Ca}$ & $<2.10 E-02$ & -- \\
\hline $\mathrm{Cd}$ & $<9.25 E-04$ & -- \\
\hline $\mathrm{Ce}$ & $<1.15 E-02$ & -- \\
\hline $\mathrm{Cr}$ & 2.13E-02 & 9E-04 \\
\hline $\mathrm{Cu}$ & $<1.44 E-03$ & -- \\
\hline $\mathrm{Fe}$ & $1.08 \mathrm{E}-02$ & $1.2 \mathrm{E}-03$ \\
\hline $\mathrm{Gd}$ & $<1.25 E-03$ & -- \\
\hline $\mathrm{K}$ & $<4.41 E-01$ & -- \\
\hline La & $<9.25 E-04$ & -- \\
\hline $\mathrm{Li}$ & $<3.94 E-03$ & - \\
\hline $\mathrm{Mg}$ & $</=3.99 E-03$ & $1.62 \mathrm{E}-03$ \\
\hline $\mathrm{Mn}$ & $</=2.20 E-03$ & $1.94 \mathrm{E}-03$ \\
\hline Mo & 1.97E-02 & 2.3E-03 \\
\hline $\mathrm{Na}$ & $2.13 E+01$ & 1E-01 \\
\hline $\mathrm{Ni}$ & $<3.47 E-03$ & -- \\
\hline$P$ & 4.45E-02 & 2.4E-03 \\
\hline $\mathrm{Pb}$ & $<1.14 E-02$ & -- \\
\hline$S$ & 6.67E-01 & $1.04 \mathrm{E}-01$ \\
\hline $\mathrm{Sb}$ & 3.67E-02 & 2.3E-03 \\
\hline $\mathrm{Si}$ & 2.24E-02 & $2.9 \mathrm{E}-03$ \\
\hline Sn & 1.30E-02 & $2.0 \mathrm{E}-03$ \\
\hline $\mathrm{Sr}$ & $<4.63 E-03$ & -- \\
\hline $\mathrm{Ti}$ & $<2.78 E-04$ & -- \\
\hline $\mathrm{Zn}$ & $<2.55 E-03$ & -- \\
\hline $\mathrm{Zr}$ & $<5.56 E-04$ & -- \\
\hline
\end{tabular}


Table 13: Undrained Bulk Saltcake AA results (g/100g)

\begin{tabular}{|c|c|c|}
\hline Sample: & \multicolumn{2}{|c|}{ T29H-B6-1 } \\
\hline$(\mathrm{g} / 100 \mathrm{~g})$ & Average & St. Dev. \\
\hline As & $<9.2 E-04$ & \\
\hline K & 8.06E-02 & 4.6E-03 \\
\hline $\mathrm{Se}$ & $<9.2 E-04$ & \\
\hline $\mathrm{Hg}$ & 7.10E-03 & 4.2E-04 \\
\hline
\end{tabular}

Table 14: Undrained Bulk Saltcake ICP-MS results (g/100g)

\begin{tabular}{|c|c|c|}
\hline Sample: & \multicolumn{2}{|c|}{ T29H-B6-1 } \\
\hline$(g / 100 g)$ & Average & St. Dev. \\
\hline Mass 59 & $<1.9 E-05$ & \\
\hline Mass 88 & 3.6E-05 & 2.5E-05 \\
\hline Mass 99 & 1.19E-03 & 4E-05 \\
\hline Mass 101 & 1.0E-04 & $3 \mathrm{E}-07$ \\
\hline Mass 133 & 1.8E-03 & 3E-05 \\
\hline Mass 135 & $2.4 \mathrm{E}-04$ & 7E-06 \\
\hline Mass 137 & 1.6E-03 & $5 \mathrm{E}-05$ \\
\hline Mass 138 & 6.0E-05 & 1.4E-05 \\
\hline Mass 230 & $<2.8 E-06$ & \\
\hline Mass 231 & $<2.8 E-06$ & \\
\hline Mass 232 & 5.7E-05 & $8 \mathrm{E}-06$ \\
\hline Mass 233 & 2.0E-05 & $3 \mathrm{E}-06$ \\
\hline Mass 234 & $3.9 \mathrm{E}-05$ & $5 \mathrm{E}-06$ \\
\hline Mass 235 & 3.1E-04 & $3 \mathrm{E}-05$ \\
\hline Mass 236 & 1.4E-04 & $1 \mathrm{E}-05$ \\
\hline Mass 237 & $1.1 \mathrm{E}-05$ & $1 \mathrm{E}-06$ \\
\hline Mass 238 & 1.47E-03 & $1.5 \mathrm{E}-04$ \\
\hline Mass 239 & 1.5E-05 & 7E-07 \\
\hline Mass 240 & $<2.8 E-06$ & \\
\hline Mass 241 & $<2.8 E-06$ & \\
\hline Mass 242 & $<2.8 E-06$ & \\
\hline Mass 243 & $<2.8 E-06$ & \\
\hline Mass 244 & $<2.8 E-06$ & \\
\hline
\end{tabular}


WSRC-TR-2004-00130

Revision 0

Table 15: Interstitial Liquid rad. chem. results (pCi/mL)

\begin{tabular}{|c|rr|}
\hline Sample: & \multicolumn{2}{|c|}{ T29H-B6-1 IL } \\
\hline$(\mathrm{pCi} / \mathrm{mL})$ & Average & St. Dev. \\
\hline${ }^{90} \mathrm{Sr}$ & $1.68 \mathrm{E}+06$ & $2 \mathrm{E}+04$ \\
\hline${ }^{137} \mathrm{Cs}$ & $2.50 \mathrm{E}+09$ & $5 \mathrm{E}+07$ \\
\hline${ }^{238} \mathrm{Pu}$ & $1.13 \mathrm{E}+04$ & $3.0 \mathrm{E}+03$ \\
\hline${ }^{239 / 240} \mathrm{Pu}$ & $3.15 \mathrm{E}+03$ & $1.48 \mathrm{E}+03$ \\
\hline${ }^{241} \mathrm{Am}$ & $2.69 \mathrm{E}+03$ & $5 \mathrm{E}+01$ \\
\hline
\end{tabular}

Table 16: Interstitial Liquid IC Anions, wet chemistry titration, and TIC/TOC results (mg/L)

\begin{tabular}{|c|c|c|}
\hline Sample: & \multicolumn{2}{|c|}{ T29H-B6-1 IL } \\
\hline$(\mathrm{mg} / \mathrm{L})$ & Average & St. Dev. \\
\hline $\mathrm{NO}_{3}{ }^{-}$ & $1.14 \mathrm{E}+05$ & $2 \mathrm{E}+03$ \\
\hline $\mathrm{NO}_{2}^{-}$ & $1.22 E+05$ & $5 E+02$ \\
\hline $\mathrm{SO}_{4}{ }^{2-}$ & $6.52 E+02$ & $0 \mathrm{E}+00$ \\
\hline $\mathrm{PO}_{4}{ }^{3-}$ & $4.38 \mathrm{E}+03$ & $5 E+01$ \\
\hline $\mathrm{Cl}^{-}$ & $</=1.81 \mathrm{E}+02$ & $5 E+01$ \\
\hline $\mathrm{F}^{-}$ & $<1.45 E+02$ & \\
\hline $\mathrm{C}_{2} \mathrm{O}_{4}{ }^{2-}$ & $<7.24 E+02$ & \\
\hline $\mathrm{CHO}_{2}^{-}$ & $<7.24 E+02$ & \\
\hline Free $\mathrm{OH}^{-}$ & $7.87 E+04$ & $6.1 \mathrm{E}+03$ \\
\hline $\mathrm{CO}_{3}{ }^{2-}$ & $<8.69 E+03$ & \\
\hline $\mathrm{CO}_{3}{ }^{2-}(\mathrm{TIC})$ & $1.26 \mathrm{E}+04$ & $2 \mathrm{E}+02$ \\
\hline TOC & $3.77 E+03$ & $4.5 \mathrm{E}+02$ \\
\hline Tot. Base (M) & $8.62 E+00$ & $6.1 \mathrm{E}-01$ \\
\hline $\mathrm{OH}^{-}$(calculated) & $1.27 E+05$ & \\
\hline
\end{tabular}


Table 17: Interstitial Liquid ICP-ES results (mg/L)

\begin{tabular}{|c|c|c|}
\hline Sample: & \multicolumn{2}{|c|}{ T29H-B6-1 IL } \\
\hline$(\mathrm{mg} / \mathrm{L})$ & Average & St. Dev. \\
\hline $\mathrm{Ag}$ & $<1.16 E+00$ & -- \\
\hline $\mathrm{Al}$ & $2.60 \mathrm{E}+04$ & $6 \mathrm{E}+02$ \\
\hline$B$ & $1.50 \mathrm{E}+02$ & $0 \mathrm{E}+00$ \\
\hline $\mathrm{Ba}$ & $3.91 \mathrm{E}+00$ & 4.3E-01 \\
\hline $\mathrm{Ca}$ & $<3.39 E+01$ & -- \\
\hline $\mathrm{Cd}$ & $<1.50 E+00$ & -- \\
\hline $\mathrm{Ce}$ & $<1.86 E+01$ & -- \\
\hline $\mathrm{Cr}$ & $4.39 \mathrm{E}+02$ & 1.1E+01 \\
\hline $\mathrm{Cu}$ & $3.01 \mathrm{E}+01$ & $3.6 \mathrm{E}+00$ \\
\hline $\mathrm{Fe}$ & $1.74 \mathrm{E}+02$ & $8.1 \mathrm{E}+01$ \\
\hline $\mathrm{Gd}$ & $<2.04 E+00$ & -- \\
\hline $\mathrm{K}$ & $4.37 \mathrm{E}+03$ & $6 \mathrm{E}+01$ \\
\hline $\mathrm{La}$ & $</=1.7 E+00$ & 2E-01 \\
\hline $\mathrm{Li}$ & $8.89 \mathrm{E}+01$ & $4.56 \mathrm{E}+01$ \\
\hline $\mathrm{Mg}$ & $1.95 \mathrm{E}+01$ & $9.6 \mathrm{E}+00$ \\
\hline $\mathrm{Mn}$ & 4.23E+01 & $1.39 \mathrm{E}+01$ \\
\hline Mo & $3.91 \mathrm{E}+02$ & $9 \mathrm{E}+00$ \\
\hline $\mathrm{Na}$ & $2.71 \mathrm{E}+05$ & $1 \mathrm{E}+03$ \\
\hline $\mathrm{Ni}$ & $1.8 \mathrm{E}+01$ & $7 E+00$ \\
\hline$P$ & $1.52 \mathrm{E}+03$ & $1 \mathrm{E}+01$ \\
\hline $\mathrm{Pb}$ & $<1.84 E+01$ & -- \\
\hline$S$ & $1.09 \mathrm{E}+03$ & $7 \mathrm{E}+01$ \\
\hline $\mathrm{Sb}$ & 7.92E+01 & $2.4 \mathrm{E}+00$ \\
\hline $\mathrm{Si}$ & $2.62 E+02$ & $3.0 \mathrm{E}+01$ \\
\hline Sn & $4.13 \mathrm{E}+01$ & $1.6 \mathrm{E}+00$ \\
\hline $\mathrm{Sr}$ & $<7.48 E+00$ & -- \\
\hline $\mathrm{Ti}$ & $<4.76 E-01$ & -- \\
\hline $\mathrm{V}$ & $1.10 \mathrm{E}+01$ & $5 E-01$ \\
\hline $\mathrm{Zn}$ & $6.19 \mathrm{E}+01$ & 7.7E+00 \\
\hline $\mathrm{Zr}$ & $1.6 \mathrm{E}+00$ & 5E-02 \\
\hline
\end{tabular}


WSRC-TR-2004-00130

Revision 0

Table 18: Interstitial Liquid ICP-MS results (mg/L)

\begin{tabular}{|c|c|c|}
\hline Sample: & \multicolumn{2}{|c|}{ T29H-B6-1 IL } \\
\hline$(\mathrm{mg} / \mathrm{L})$ & Average & St. Dev. \\
\hline Mass 59 & 5.6E-01 & $1 \mathrm{E}-02$ \\
\hline Mass 88 & $<1.4 E-01$ & -- \\
\hline Mass 99 & $3.81 \mathrm{E}+01$ & $3 \mathrm{E}-01$ \\
\hline Mass 101 & $2.42 \mathrm{E}+00$ & $3 E-02$ \\
\hline Mass 133 & $5.73 E+01$ & 9E-01 \\
\hline Mass 135 & $8.42 E+00$ & $9.7 \mathrm{E}-02$ \\
\hline Mass 137 & $3.01 \mathrm{E}+01$ & $6 \mathrm{E}-01$ \\
\hline Mass 138 & $3.8 \mathrm{E}-01$ & $2 \mathrm{E}-02$ \\
\hline Mass 230 & $<5.0 E-02$ & -- \\
\hline Mass 231 & $<5.0 E-02$ & -- \\
\hline Mass 232 & $<5.0 E-02$ & -- \\
\hline Mass 233 & $<5.0 E-02$ & -- \\
\hline Mass 234 & $<5.0 E-02$ & -- \\
\hline Mass 235 & 1.09E-01 & $3.0 \mathrm{E}-02$ \\
\hline Mass 236 & $6.1 \mathrm{E}-02$ & 3E-04 \\
\hline Mass 237 & $<5.0 E-02$ & -- \\
\hline Mass 238 & $4.15 E+00$ & 1.1E-01 \\
\hline Mass 239 & $<5.0 E-02$ & -- \\
\hline Mass 240 & $<5.0 E-02$ & -- \\
\hline Mass 241 & $<5.0 E-02$ & -- \\
\hline Mass 242 & $<5.0 E-02$ & -- \\
\hline Mass 243 & $<5.0 E-02$ & -- \\
\hline Mass 244 & $<5.0 E-02$ & -- \\
\hline
\end{tabular}


Table 19: Tank 29H supernate rad. chem. results $(\mathrm{pCi} / \mathrm{mL})$

\begin{tabular}{|c|rr|rrr|rc|}
\hline Tank $29 \mathrm{H}$ & \multicolumn{2}{|c|}{ As Received } & \multicolumn{2}{c|}{$0.45-\mu \mathrm{m}$ Filtrate } & \multicolumn{2}{c|}{$0.1-\mu \mathrm{m}$ Filtrate } \\
\hline$(\mathrm{pCi} / \mathrm{mL})$ & Average & St. Dev. & \multicolumn{2}{|c|}{ Average } & \multicolumn{1}{c|}{ St. Dev. } & Average & St. Dev. \\
\hline${ }^{14} \mathrm{C}$ & \multicolumn{2}{|c|}{--} & & $1.20 \mathrm{E}+03$ & -- & -- & \\
\hline${ }^{90} \mathrm{Sr}{ }^{\text {a }}$ & $1.44 \mathrm{E}+04$ & $3.3 \mathrm{E}+03$ & $1.59 \mathrm{E}+05$ & $3.3 \mathrm{E}+04$ & $1.21 \mathrm{E}+05$ & $8 \mathrm{E}+02$ \\
\hline${ }^{137} \mathrm{Cs}$ & $6.92 \mathrm{E}+08$ & $0 \mathrm{E}+00$ & $7.15 \mathrm{E}+08$ & $8 \mathrm{E}+06$ & $7.21 \mathrm{E}+08$ & $8 \mathrm{E}+06$ \\
\hline${ }^{238} \mathrm{Pu}$ & $1.32 \mathrm{E}+05$ & $2.8 \mathrm{E}+03$ & $3.65 \mathrm{E}+04$ & $1.4 \mathrm{E}+03$ & $3.40 \mathrm{E}+04$ & $2.8 \mathrm{E}+03$ \\
\hline${ }^{239 / 240} \mathrm{Pu}$ & $2.66 \mathrm{E}+03$ & $1 \mathrm{E}+01$ & $1.10 \mathrm{E}+03$ & $4 \mathrm{E}+01$ & $<8.31 \mathrm{E}+02$ & -- \\
\hline${ }^{241} \mathrm{Am}$ & $<6.30 \mathrm{E}+02$ & -- & $<6.84 \mathrm{E}+02$ & -- & $<4.83 \mathrm{E}+02$ & -- \\
\hline
\end{tabular}

Note a: Unexpectedly, the as-received sample had lower amounts of ${ }^{90} \mathrm{Sr}$ than the filtered samples

Table 20: Tank 29H supernate IC anions, wet chemistry titration, and TIC/TOC results (mg/L)

\begin{tabular}{|c|cc|}
\hline Tank 29H & \multicolumn{2}{|c|}{$0.45-\mu \mathrm{m}$ Filtrate } \\
\hline$(\mathrm{mg} / \mathrm{L})$ & Average & St. Dev. \\
\hline $\mathrm{NO}_{3}{ }^{-}$ & $1.05 \mathrm{E}+05$ & $3 \mathrm{E}+03$ \\
\hline $\mathrm{NO}_{2}{ }^{-}$ & $3.24 \mathrm{E}+04$ & $3 \mathrm{E}+02$ \\
\hline $\mathrm{SO}_{4}{ }^{2-}$ & $6.76 \mathrm{E}+03$ & $1.3 \mathrm{E}+02$ \\
\hline $\mathrm{PO}_{4}{ }^{3-}$ & $3.91 \mathrm{E}+02$ & $4.2 \mathrm{E}+01$ \\
\hline $\mathrm{Cl}^{-}$ & $6.01 \mathrm{E}+01$ & $0 \mathrm{E}+00$ \\
\hline $\mathrm{F}^{-}$ & $1.80 \mathrm{E}+01$ & $0 \mathrm{E}+00$ \\
\hline $\mathrm{C}_{2} \mathrm{O}_{4}{ }^{2-}$ & $9.01 \mathrm{E}+01$ & $4.25 \mathrm{E}+01$ \\
\hline $\mathrm{CHO}_{2}{ }^{-}$ & $<6.01 \mathrm{E}+02$ & -- \\
\hline $\mathrm{Total} \mathrm{Base}(\mathrm{M})^{-}$ & $3.07 \mathrm{E}+00$ & $4.7 \mathrm{E}-02$ \\
\hline $\mathrm{Free} \mathrm{OH}^{-}$ & $2.56 \mathrm{E}+04$ & $8.7 \mathrm{E}+02$ \\
\hline $\mathrm{CO}_{3}{ }^{2-}(\mathrm{TIC})$ & $2.37 \mathrm{E}+04$ & $6.4 \mathrm{E}+02$ \\
\hline TOC & $3.79 \mathrm{E}+03$ & $1.3 \mathrm{E}+02$ \\
\hline $\mathrm{OH}^{-}$(calculated) & $4.08 \mathrm{E}+04$ & \\
\hline
\end{tabular}


WSRC-TR-2004-00130

Revision 0

Table 21: Tank 29H supernate ICP-ES results (mg/L)

\begin{tabular}{|c|c|c|c|c|c|c|}
\hline Tank 29H & \multicolumn{2}{|c|}{ As Received } & \multicolumn{2}{|c|}{$0.45-\mu \mathrm{m}$ Filtrate } & \multicolumn{2}{|c|}{$0.1-\mu \mathrm{m}$ Filtrate } \\
\hline$(\mathrm{mg} / \mathrm{L})$ & Average & St. Dev. & Average & St. Dev. & Average & St. Dev. \\
\hline $\mathrm{Ag}$ & $<9.26 E+00$ & -- & $<9.24 E+00$ & -- & $<8.23 E+00$ & -- \\
\hline $\mathrm{Al}$ & $2.49 \mathrm{E}+03$ & $0 \mathrm{E}+00$ & $8.47 \mathrm{E}+03$ & $6.19 E+03$ & $6.44 \mathrm{E}+03$ & $2.23 E+03$ \\
\hline$B$ & $<1.00 E+03$ & -- & $<9.97 E+02$ & -- & $<8.90 E+02$ & -- \\
\hline $\mathrm{Ba}$ & $<9.26 E+00$ & -- & $<9.24 E+00$ & -- & $<8.23 E+00$ & -- \\
\hline $\mathrm{Ca}$ & $<2.80 E+02$ & -- & $<2.78 E+02$ & -- & $<2.48 E+02$ & -- \\
\hline $\mathrm{Cd}$ & $<1.23 E+01$ & -- & $<1.23 E+01$ & -- & $<1.10 E+01$ & -- \\
\hline $\mathrm{Ce}$ & $<1.54 E+02$ & -- & $<1.52 E+02$ & -- & $<1.36 E+02$ & -- \\
\hline $\mathrm{Cr}$ & $8.13 \mathrm{E}+01$ & $1.1 \mathrm{E}+00$ & $1.28 \mathrm{E}+02$ & 5.7E+01 & $1.08 \mathrm{E}+02$ & $1.2 \mathrm{E}+01$ \\
\hline $\mathrm{Cu}$ & $<1.92 E+01$ & -- & $<1.90 E+01$ & -- & $<1.70 E+01$ & -- \\
\hline $\mathrm{Fe}$ & $<1.36 E+01$ & -- & $<1.35 E+01$ & -- & $<1.21 E+01$ & -- \\
\hline $\mathrm{Gd}$ & $<1.66 E+01$ & -- & $<1.66 E+01$ & -- & $<1.49 E+01$ & -- \\
\hline $\mathrm{K}$ & $<5.88 E+03$ & -- & $<5.86 E+03$ & -- & $<5.23 E+03$ & -- \\
\hline La & $<1.23 E+01$ & -- & $<1.23 E+01$ & -- & $<1.10 E+01$ & -- \\
\hline $\mathrm{Li}$ & $<5.24 E+01$ & -- & $<5.23 E+01$ & -- & $<4.66 E+01$ & -- \\
\hline $\mathrm{Mg}$ & $<3.83 E+01$ & -- & $<3.82 E+01$ & -- & $<3.40 E+01$ & -- \\
\hline $\mathrm{Mn}$ & $<1.36 E+01$ & -- & $<1.35 E+01$ & -- & $<1.21 E+01$ & -- \\
\hline Mo & $<1.26 E+02$ & -- & $<1.26 E+02$ & -- & $1.15 \mathrm{E}+02$ & $4 \mathrm{E}+00$ \\
\hline $\mathrm{Na}$ & $1.12 \mathrm{E}+05$ & $3 \mathrm{E}+03$ & $1.26 \mathrm{E}+05$ & $1.3 \mathrm{E}+04$ & $1.16 \mathrm{E}+05$ & $4 \mathrm{E}+03$ \\
\hline $\mathrm{Ni}$ & $<4.62 E+01$ & -- & $<4.61 E+01$ & -- & $<4.12 E+01$ & -- \\
\hline $\mathrm{P}$ & $<3.00 E+02$ & -- & $<2.99 E+02$ & -- & $</=2.67 E+02$ & $2 \mathrm{E}+00$ \\
\hline $\mathrm{Pb}$ & $<1.52 E+02$ & -- & $<1.51 E+02$ & -- & $<1.35 E+02$ & -- \\
\hline$S$ & $2.46 \mathrm{E}+03$ & $2 \mathrm{E}+01$ & $1.68 \mathrm{E}+03$ & $8.2 \mathrm{E}+02$ & $2.41 \mathrm{E}+03$ & $5.3 \mathrm{E}+01$ \\
\hline $\mathrm{Sb}$ & $<9.32 E+01$ & -- & $<9.30 E+01$ & -- & $<8.29 E+01$ & -- \\
\hline $\mathrm{Si}$ & $8.64 \mathrm{E}+02$ & $6.8 \mathrm{E}+01$ & $8.19 \mathrm{E}+02$ & $3.6 \mathrm{E}+01$ & $6.77 \mathrm{E}+02$ & $7.4 \mathrm{E}+01$ \\
\hline Sn & $<1.51 E+02$ & -- & $<1.51 E+02$ & -- & $<1.35 E+02$ & -- \\
\hline $\mathrm{Sr}$ & $<6.17 E+01$ & -- & $<6.16 E+01$ & -- & $<5.49 E+01$ & -- \\
\hline $\mathrm{Ti}$ & $<3.70 E+00$ & -- & $<3.69 E+00$ & -- & $<3.29 E+00$ & -- \\
\hline $\mathrm{V}$ & $<6.79 E+00$ & -- & $<6.77 E+00$ & -- & $<6.04 E+00$ & -- \\
\hline $\mathrm{Zn}$ & $<3.39 E+01$ & -- & $<3.39 E+01$ & -- & $<3.02 E+01$ & -- \\
\hline $\mathrm{Zr}$ & $<7.41 E+00$ & -- & $<7.38 E+00$ & -- & $<6.59 E+00$ & -- \\
\hline
\end{tabular}


Table 22: Tank 29H supernate ICP-MS results ( $\mathrm{mg} / \mathrm{L}$ )

\begin{tabular}{|c|c|c|c|c|c|c|}
\hline Tank 29H & \multicolumn{2}{|c|}{ As Received } & \multicolumn{2}{|c|}{$0.45-\mu \mathrm{m}$ Filtrate } & \multicolumn{2}{|c|}{$0.1-\mu \mathrm{m}$ Filtrate } \\
\hline$(\mathrm{mg} / \mathrm{L})$ & Average & St. Dev. & Average & St. Dev. & Average & St. Dev. \\
\hline Mass 59 & $<2.8 E-01$ & -- & $<2.8 E-01$ & -- & $<2.5 E-01$ & -- \\
\hline Mass 88 & $<2.4 E-01$ & -- & $<2.4 E-01$ & -- & $</=2.4 \mathrm{E}-01$ & $4 \mathrm{E}-02$ \\
\hline Mass 99 & $1.04 \mathrm{E}+01$ & $8 \mathrm{E}-01$ & $1.08 \mathrm{E}+01$ & $6 \mathrm{E}-01$ & $1.03 E+01$ & $1 \mathrm{E}-02$ \\
\hline Mass 101 & 4.3E-01 & $1 \mathrm{E}-02$ & 3.8E-01 & $3 E-03$ & 3.3E-01 & $2 E-03$ \\
\hline Mass 133 & $1.67 \mathrm{E}+01$ & 6E-01 & $1.69 \mathrm{E}+01$ & $8 \mathrm{E}-01$ & $1.61 \mathrm{E}+01$ & $4 \mathrm{E}-01$ \\
\hline Mass 135 & $2.39 \mathrm{E}+00$ & 9E-02 & $2.46 \mathrm{E}+00$ & 6E-03 & $2.35 \mathrm{E}+00$ & $2 \mathrm{E}-02$ \\
\hline Mass 137 & $8.95 E+00$ & 2E-01 & $9.04 \mathrm{E}+00$ & 2.7E-01 & $8.72 E+00$ & 9E-02 \\
\hline Mass 138 & $<1.5 E-01$ & -- & $5.0 \mathrm{E}-01$ & 1E-02 & $6.4 \mathrm{E}-01$ & $6.3 \mathrm{E}-01$ \\
\hline Mass 230 & $<8.3 E-02$ & -- & $<8.3 E-02$ & -- & $<7.4 E-02$ & -- \\
\hline Mass 231 & $<8.3 E-02$ & -- & $<8.3 E-02$ & -- & $<7.4 E-02$ & -- \\
\hline Mass 232 & $<8.3 E-02$ & -- & $<8.3 E-02$ & -- & $<7.4 E-02$ & -- \\
\hline Mass 233 & $<8.3 E-02$ & -- & $<8.3 E-02$ & -- & $<7.4 E-02$ & -- \\
\hline Mass 234 & $<8.3 E-02$ & -- & $<8.3 E-02$ & -- & $<7.4 E-02$ & -- \\
\hline Mass 235 & 2.31E-01 & $1.5 \mathrm{E}-02$ & 1.46E-01 & $2.2 \mathrm{E}-02$ & 1.34E-01 & $9.2 \mathrm{E}-03$ \\
\hline Mass 236 & 8.85E-02 & 8.0E-03 & $<8.3 E-02$ & -- & $<7.4 E-02$ & -- \\
\hline Mass 237 & $<8.3 E-02$ & -- & $<8.3 E-02$ & -- & $<7.4 E-02$ & -- \\
\hline Mass 238 & $1.68 \mathrm{E}+00$ & 1.7E-03 & $1.33 \mathrm{E}+00$ & $8.8 \mathrm{E}-03$ & $1.14 \mathrm{E}+00$ & $2.5 \mathrm{E}-04$ \\
\hline Mass 239 & $<8.3 E-02$ & -- & $<8.3 E-02$ & -- & $<7.4 E-02$ & -- \\
\hline Mass 240 & $<8.3 E-02$ & -- & $<8.3 E-02$ & -- & $<7.4 E-02$ & -- \\
\hline Mass 241 & $<8.3 E-02$ & -- & $<8.3 E-02$ & -- & $<7.4 E-02$ & -- \\
\hline Mass 242 & $<8.3 E-02$ & -- & $<8.3 E-02$ & -- & $<7.4 E-02$ & -- \\
\hline Mass 243 & $<8.3 E-02$ & -- & $<8.3 E-02$ & -- & $<7.4 E-02$ & -- \\
\hline Mass 244 & $<8.3 E-02$ & -- & $<8.3 E-02$ & -- & $<7.4 E-02$ & -- \\
\hline
\end{tabular}

Table 23: Tank 29H supernate AA results (mg/L)

\begin{tabular}{|c|rc|r|c|c|c|}
\hline Tank 29H & \multicolumn{2}{|c|}{ As Received } & \multicolumn{2}{|c|}{$0.45-\mu \mathrm{m}$ Filtrate } & \multicolumn{2}{c|}{$0.1-\mu \mathrm{m}$ Filtrate } \\
\hline$(\mathrm{mg} / \mathrm{L})$ & \multicolumn{1}{|c|}{ Average } & St. Dev. & Average & St. Dev. & Average & St. Dev. \\
\hline As & $<3.1 E+00$ & -- & $<3.1 E+00$ & -- & $<2.7 E+00$ & -- \\
\hline $\mathrm{K}$ & $9.4 \mathrm{E}+02$ & $1 \mathrm{E}+01$ & $9.7 \mathrm{E}+02$ & $2 \mathrm{E}+01$ & $9.8 \mathrm{E}+02$ & $9.6 \mathrm{E}+01$ \\
\hline $\mathrm{Se}$ & $<3.1 \mathrm{E}+00$ & -- & $<3.1 \mathrm{E}+00$ & -- & $<2.7 E+00$ & -- \\
\hline $\mathrm{Hg}$ & $7.2 \mathrm{E}+01$ & $9 \mathrm{E}+00$ & $4.7 \mathrm{E}+01$ & $3 \mathrm{E}-01$ & $4.4 \mathrm{E}+01$ & $5 \mathrm{E}-01$ \\
\hline
\end{tabular}

